\title{
Aktív befektetési stratégiák teljesítményének mérése tiszta faktorportfóliókkal*
}

\author{
Fain Máté - Naffa Helena
}

A cikkben többváltozós keresztmetszeti regressziók alapján összeállított tiszta faktorportfóliókkal azt vizsgáljuk, hogy ezen aktiv befektetési stratégiákkal lehetett-e többlethozamot elérni a passziv stratégiához képest. Hipotézisünk a piaci hatékonyság tesztjeként is értelmezhetö. Az elemzésbe tíz stílusfaktort vontunk be. Empirikus vizsgálatunk azt mutatja, hogy az elmúlt közel 20 évben szignifikáns pozitiv többlethozamot a tiszta értékfaktor konszenzusos vételével lehetett elérni. A szakirodalomban pozitiv hozamtöbblettel jellemzett méret és momentumfaktorok tanulmányunkban nem szignifikánsak. A kockázatosságot megragadó faktorok (eredmény változékonysága, volatilitás, tőkeáttétel) többlethozama szignifikáns és negativ, ami egybeesik várakozásainkkal, azaz sikeres konszenzusos eladási befektetési stratégiát lehetett e faktorokra épiteni. A várakozásainkkal ellentétes eredményekre jutottunk a jövedelmezőségi, növekedési és kereskedési aktivitást mérő faktoroknál, így többlethozamot a kontra eladási stratégiával lehetett elérni. Kutatási eredményeink összhangban vannak a piaci hatékonyságvizsgálatok gyenge formájával.

Journal of Economic Literature (JEL) kódok: G11, G12, G14, G15.

Kulcsszavak: részvénypiacok, eszközárazás, hozam, tiszta faktorportfólió, többváltozós regresszió, teljesítménymérés, piaci hatékonyság

\section{Bevezetés}

A pénzügyi befektetésekkel foglalkozó gyakorló szakembereket és a tudományos élet kutatóit mindig élénken foglalkoztatta a kérdés, miképpen lehetne előre jelezni és értelmezni az értékpapírok méltányos, a kockázatot is tükröző várható hozamát ${ }^{1}$, végső soron a részvényárfolyamot ${ }^{2}$. Az elmúlt évtizedek során megalkotott külön-

\footnotetext{
* A jelen kiadványban megjelenő írások a szerzők nézeteit tartalmazzák, ami nem feltétlenül egyezik a Magyar Nemzeti Bank hivatalos álláspontjával.
}

Fain Máté a Budapesti Corvinus Egyetem PhD-hallgatója. E-mail: mate.fain@uni-corvinus.hu Naffa Helena a Budapesti Corvinus Egyetem adjunktusa. E-mail: helena.naffa@uni-corvinus.hu

A magyar nyelvű kézirat első változata 2018. december 17-én érkezett szerkesztőségünkbe.

DOI: http://doi.org/10.25201/HSZ.18.2.5287

${ }^{1}$ A várható és az elvárt hozamok között érdemi különbség van, amit fontos szem előtt tartani. Lásd példaként Fernandez (2015) és Fernandez - Acín (2015) munkáit.

2 Precízebben fogalmazva, a befektetőket a teljes hozam érdekli, vagyis az osztalékhozam és az árfolyam változásából eredő hozam összessége. Tanulmányunkban hozam alatt mindvégig a teljes hozamot fogjuk érteni. 
féle tőkepiaci elméletek és alkalmazások kiemelt célja volt a hozamokat befolyásoló legkülönfélébb faktorok azonosítása, valamint érdemi kapcsolat teremtése a várható hozam és a kockázat között.

Miképpen változott a pénzügyi-befektetési gondolkodás az elmúlt bő fél évszázadban? Az 1930-as évekre tehető a részvények belső értéken alapuló elemzési keretrendszerének a kialakulása. A korszak meghatározó módszertani könyvei Williams ${ }^{3}$ és a Graham - Dodd szerzőpáros ${ }^{4}$ nevéhez füződnek (Malkiel 2001). Az 1950-es, 1960-as évek a modern pénzügyek megszületésének és megszilárdulásának az évtizedei. Az időszakot olyan közgazdászok és nevükhöz kapcsolódó elméletek fémjelezik, mint Markowitz (1952) modern portfólióelmélete, vagy a tőkepiaci árfolyamok modellje (CAPM) Sharpe (1964), Lintner (1965) és Mossin (1966) munkásságának eredményeként. A kor gondolkodását a racionális befektető, a piacok információs szempontból hatékony múködése (lásd Fama 1970-ben megjelent írását), a hozamalakulást véletlen bolyongásként értelmező megközelítések határozták meg.

Hozzávetőlegesen az 1970-es évektől egyre inkább beszüremlik a pénzügyi gondolkodásba az a vélekedés, amely szerint a piacok talán mégsem tekinthetők „annyira” hatékonynak, mint ahogyan korábban feltételezték, s a befektetők nem viselkednek mindig racionálisan ${ }^{5}$. Mind többször kérdőjeleződnek meg a CAPM előfeltevései, következtetései; válaszul előtérbe kerül a többfaktoros modellek alkalmazása (lásd Ross 1976-os arbitrált árfolyamok elméletét). A szakirodalom többnyire a Fama French szerzőpárosnak tulajdonítja a többfaktoros modellek elterjedését és népszerűvé válását; ugyanakkor a tématerület kutatói napjainkra odáig jutottak, hogy százas nagyságrendben azonosítottak hozammagyarázó faktorokat. Mindenesetre nem könnyű eldönteni, hogy ebben a faktoruniverzumban melyek tekinthetők statisztikailag és gyakorlati interpretálhatóság szempontjából egyaránt szignifikánsnak. Cochrane (2011) találóan faktor-állatkertnek nevezte el ezt a sokaságot.

Tanulmányunkban többváltozós keresztmetszeti regressziók alapján összeállított tiszta faktorportfóliókkal (pure factor portfolios) azt vizsgáljuk, hogy ezen aktív befektetési stratégiákkal lehetett-e többlethozamot elérni a passzív stratégiához képest. Tanulmányunk hipotézise a piaci hatékonyság tesztjeként is értelmezhető. Az elemzési univerzumunk az Egyesült Államok részvénypiaca 2000 és 2018 között, a benchmark a Russell 3000 Index. A faktorok teljesítményének értékeléshez használt mutatók a Jensen-féle alfa és a Sharpe-ráta.

\footnotetext{
${ }^{3}$ The Theory of Investment Value

${ }^{4}$ Security Analysis

${ }^{5}$ Az időszak során egyre inkább teret nyert a viselkedési pénzügytan, amelynek alapjait Kahneman és Tversky rakták le 1979-ben megjelent korszakos múvükben (Prospect Theory).
} 
A következő fejezetekben először a tőkepiaci árfolyamok modellje és a hatékony piacok elmélete kritikájaként megszületett, a piaci árazási anomáliákat bemutató fontosabb tanulmányokat ismertetjük (2. fejezet). Az anomáliákat követően különféle többfaktoros hozammagyarázó modellek kerülnek a vizsgálódás fókuszába. A hangsúly elsősorban Fama és French munkásságán lesz (3. fejezet). A szakirodalmi áttekintést követően olyan tanulmányokat mutatunk be, amelyek tiszta faktorportfóliókat alkalmaztak különféle hozamok elemzésére (4. és 5. fejezet). Tanulmányunk empirikus részét (7. fejezet) megelőzi a felhasznált adatbázis (6. fejezet) részletes ismertetése. A 8. fejezetben összegezzük tanulmányunk főbb üzeneteit.

\section{Piaci anomáliák}

Mielőtt a piaci anomáliák részletesebb tárgyalásába belekezdenénk, fontosnak tartjuk hangsúlyozni, hogy a piacok hatékonyságának tesztelése, továbbá a részvénybefektetések kockázattal korrigált, abnormális hozamának számszerúsítése voltaképpen egyet jelent az általánosan elterjedt árazási modellek (leginkább a CAPM) tesztelésével is. Chien-Ting (1999) alapján a benchmarknak használható CAPM-mel kapcsolatos anomáliák alapvetően három okra vezethetők vissza: 1) mérési hibákra, 2) a modell kiinduló alapfeltevéseinek tarthatatlanságára, és 3) modellspecifikációs hibákra.

A módszertani, mérési hibák közé a modellváltozók, így a kockázatmentes hozam, a béta és a piaci kockázati prémium helytelen mérése sorolható, hiszen ezek tartalmára nem ad gyakorlati iránymutatást az elméleti CAPM ${ }^{6}$. A helytelen alapfeltételezések között leginkább a hatékony piacok hipotézisét (EMH) szokás emlegetni. A modellspecifikációs hibák statisztikai eredetűek. Ide lehet sorolni - többek között - a hiányzó magyarázó változók esetét (omitted variables bias). Utóbbi hibák megléte nem (feltétlenül) jelenti azt, hogy a piacok ne lennének hatékonyak, „csupán” azt, hogy nem sikerült minden magyarázó faktort figyelembe venni.

A tiszta faktorportfóliók alkalmazásával a Chien-Ting-féle klasszifikáció alapján elsősorban a modellspecifikációs, másodsorban a mérési csoportba tartozó hibákat kívánjuk orvosolni. A modellezés során mindenesetre szem előtt tartjuk Damodaran (2012) azon megjegyzését, hogy amennyiben egy hozamokat magyarázó elemzés eredménye nem érzékeny a különféle modellspecifikációkra, akkor sokkal inkább valószínú, hogy a piaci hatékonyság hiányával találkoztunk, azaz nem követtünk el modellspecifikációs hibát.

\footnotetext{
${ }^{6} \mathrm{~A}$ béta, piaci kockázati prémium időbeli állandósága sem tartható feltételezés.
} 
A fentiek értelmében a CAPM egyik kulcsfeltétele a tökéletes (versenyzői) piacok meglétére vonatkozik (lásd Lintner 1965:22). A tökéletes piacok viszont feltételezik a piacok hatékonyságát is. Ugyanakkor a hatékony piacoknak nem feltétlenül kell tökéletesnek lenniük (Kasper 1997). Praktikusan mindez azt jelenti, hogy amennyiben sérülnek a hatékony piac elméletének feltételei, akkor a CAPM tökéletes piaccal kapcsolatos előfeltevései sem állnak fenn. Az utóbbi évtizedekben számos kutatás született olyan piaci anomáliákkal kapcsolatban, amelyek, első látásra úgy tűnnek, megsértik a piacok hatékonyságára vonatkozó feltevéseket. Az alábbiakban e piaci anomáliák közül emelünk ki néhányat (a teljesség igénye nélkül), majd a következő alfejezetben olyan többfaktoros modelleket is bemutatunk, amelyek a hozamok magyarázatára felhasználják e faktorok némelyikét. A bemutatott anomáliák alapján történő mindennapi kereskedés, portfólió-optimalizálás (az alfa keresése) egy-egy befektetési stílusnak tekinthető.

A momentum (másképpen lendület) hatást tömören a következőképpen lehet leírni: a mostani jó teljesítményt jó, míg a mostani rossz teljesítményt rossz teljesítmény fogja követni. Statisztikai szóhasználattal élve, az egymást időben követő hozamok között pozitív autokorreláció figyelhető meg. Az anomáliával kapcsolatos valódi kérdés az időtényező: milyen távon figyelhető meg a lendület hatása? Fama és Blume (1966) napi hozamokon vizsgálta a pozitív autokorreláció meglétét, átemelve Alexander 1964-es munkájának szűrő (filter) technikáját. Lo és MacKinlay (1988), valamint Conrad és Kaul (1988) heti hozamokat elemzett. A következtetésük lényege, hogy bár megfigyelhető némi pozitív autokorreláció, az nem elégséges ahhoz, hogy érdemi profitszerzésre nyíljon lehetőség. Jegadeesh és Titman 1993-ban publikált tanulmánya már hosszabb időtávon vizsgálódott. A szerzők 3-12 hónapos időhorizont alapján szignifikánsnak találták a momentumfaktort. A szerzőpáros 2001-ben megjelent tanulmánya megerősíti az 1993-as megfigyeléseket.

A momentumhoz szorosan kapcsolódik a reverzió (korrekció) jelensége. Ez éppen negatív autokorrelációt feltételez, azaz a piacokra jellemző, hogy egy idő után büntetik a korábban „nyertes” papírokat, a „vesztes” részvényeket pedig jutalmazzák, vagyis a piac hajlamos a túlreagálásokra. Többek között De Bondt és Thaler (1985 és 1987), Howe (1986), Brown és Harlow (1988) is vizsgálta a piacok túlreagálását, arra jutva, hogy hosszabb távon, években mérve tapasztalható reverziós jelenség. De Bondt és Thaler eredményei alapján az eredetileg „vesztes” portfólió 36 hónappal később már hozzávetőlegesen 25 százalékkal jobban teljesített, mint a korábbi „nyertes”. Howe úgy találta, hogy a korábban nagy nyereséget elkönyvelő részvények egy évvel a jó hírek után 30 százalékkal a piac alatt teljesítettek. Összességében, rövidebb távon a momentumfaktor, hosszabb távon a reverziós hatás látszik érvényesülni

\footnotetext{
${ }^{7}$ A momentum és reverziós hatáshoz szorosan tapadó fogalom az „átlaghoz való visszatérés” koncepciója. Lásd De Bondt - Thaler (1989).
} 
A mérethatást, amelyet kisvállalat-hatásként is emlegetnek, eredetileg Banz (1981) írta le. Ennek az anomáliának a lényege, hogy a kisebb vállalatokkal elérhető hozam szignifikánsan magasabb, mint a kockázattal korrigált méltányos hozam. Banz nagymintán végezte el az elemzést: adatbázisát az 1926 és 1975 között legalább öt éven át a New York-i értéktőzsdén jegyzett cégek alkották. Kutatása alapján a legkisebb vállalatoknál volt megfigyelhető a legnagyobb eltérés (innen is származik a kisvállalat-hatás elnevezés). Számos publikáció próbálta megmagyarázni a többlethozam okát. Ezek egy része úgy tekint a kisvállalkozásokra, mint a nagy portfóliókezelők által elhanyagolt cégekre (neglected-firm effect), és ennek köszönhetően lehet magasabb kockázatarányos hozamra szert tenni (Carvell - Strebel 1987; Arbel et al. 1983). Egy, az 1990-es években született tanulmány (Beard - Sias 1997) ugyanakkor arra a következtetésre jutott, hogy az elhanyagolt vállalat effektus újabban már nem létezik. Más kutatások (lásd Reinganum 1983, Ritter 1988) az év végi-év eleji adómegfontolásokat vették alapul, amelyek elvezettek a felismeréshez, hogy a mérethatás „csupán” januárban jelentkezik (January effect).

Az érték (value) faktor alapján olyan vállalati fundamentumokat azonosítunk, amelyek érdemben meghatározhatják az értéket, így azonosíthatóvá válnak az alul- vagy felülértékelt részvények. A széleskörűen alkalmazott value faktorok az árfolyam/ nyereség ráta $(P / E)$, ennek inverze, a nyereséghozam $(E / P)$, a saját tőke piaci érték-könyv szerinti érték hányadosa (P/BV), az osztalékhozam (DIV/P). Basu (1977, 1983) empirikus vizsgálatai megerősítették azt a befektetők körében elterjedt vélekedést, hogy az alacsony $\mathrm{P} / \mathrm{E}$ rátával (magas $\mathrm{E} / \mathrm{P}$ ) rendelkező értékpapírok alulértékeltek, és többlethozamot biztosíthatnak. Fama és French (1992) rámutatott, hogy az 1963 és 1990 között magas BV/P mutatóval rendelkező NYSE-en, AMEX-en és NASDAQ-on jegyzett cégek számottevő többlethozamot értek el az alacsony BV/P rátával rendelkező vállalatokhoz képest. Rosenberg et al. (1985), Chan et al. (1991) és Capaul et al. (1993) lényegében hasonló következtetésekre jutott eltérő időszakok és más-más piacok vonatkozásában.

Az értékfaktorokhoz kívánkozik Robert Novy-Marx 2013-as tanulmánya, amelyben kissé másfajta jövedelmezőségi faktor magyarázó ereje mellett érvel. Meglátása szerint a bruttó fedezet ${ }^{8}$ a BV/P megfelelő alternatívája, amelyen „nem fognak” a könyv szerinti érték-piaci érték hányados magyarázó ereje ellen felhozott kritikák (lásd többek között a Fama és French 1992-ben megjelent tanulmányára született ellenérveket). Ezt azzal indokolja, hogy a jövedelmezően múködő vállalatok esetében alacsonyabb az operatív tőkeáttétel, így biztosabbak és hosszabb távon fenntarthatóbbak a pozitív vállalati pénzáramok.

\footnotetext{
${ }^{8}$ Az értékesítés nettó árbevétele és az ELÁBÉ különbözete.
} 
Ugyancsak érdekes és viszonylag újszerü téma az alacsony volatilitás vagy alacsony béta anomália (low volatility, low beta anomaly), amelynek a lényege, hogy a magas volatilitással (bétával) rendelkező vállalkozások szignifikánsan alulteljesítik az alacsony kockázatú (bétájú) befektetéseket. Baker et al. (2011) kiemeli, hogy az eredmények nem teljesen újszerűek, de a korábbi időszakok szerzői nem hangsúlyozták e jelenséget kellő mértékben. Hasonló következtetésre jutottak mások is, lásd többek között Frazzini - Pedersen (2014), Ang et al. (2006, 2009), Blitz és van Vliet (2007), Bali et al. (2011) munkáit.

\section{Többfaktoros modellek}

A szakirodalomban legtöbbször hivatkozott többfaktoros modellek Fama és French $(\mathrm{FF})^{9}$ munkásságához füződnek. Természetesen a szakirodalom FF-en túl is bővelkedik jelentős kutatásokban. Megemlíthetjük a faktormodellekkel elsők között mind elméleti, mind a gyakorlati alkalmazások szintjén foglalkozó Barr Rosenberg nevét. Rosenberg 1974-es munkájában statisztikai megalapozását adta a többfaktoros modelleknek. Később, kollégáival karöltve, empirikus elemzéseket is készített, amelyekben kiemelt szerepet tulajdonított többek között az iparágnak, a pénzügyi beszámolók adatainak (lásd - példálózó jelleggel - Rosenberg - McKibben 1973; Rosenberg - Guy 1976). Szintén sokat idézett Carhart (1997) munkája, amely Fama - French (1996) háromfaktoros modelljének momentumfaktorral történő kiterjesztése. A kelet-közép-európai régióból utalhatunk Zaremba - Konieczka (2017), Berlinger - Walter (1999) vagy Naffa (2009) munkáira.

Chen és szerzőtársai 1986-ban megjelent munkájukban különféle makrogazdasági faktorokat azonosítottak, úgymint az iparági termelés, várt és nem várt inflációs változások, a kötvények kockázati prémiumának és a határidős prémiumoknak nem várt változásai, amelyek befolyásolhatják a várható hozamot. Az előzőekben bemutatott Fama - MacBeth kétlépcsős regressziós technikát alkalmazva arra a megállapításra jutottak, hogy az ipari termelésnek, a nem várt inflációnak és a kötvények hozamprémiumának van szignifikáns magyarázó ereje.

Fama és French (1992) tanulmánya a hozamok magyarázatára két, a tudományos köröket és gyakorló szakembereket jelentősen megmozgató állítással élt. A szerzők egyrészt azt találták, hogy az 1963 és 1990 közötti hozamokat érdemben meghatározta két változó: a méret és a BV/P ráta. A hozamok és a magyarázó változók közötti reláció értelmében a magas BV/P hányadossal és a relatíve kis mérettel rendelkező

\footnotetext{
${ }^{9}$ Fama és French korai munkásságának módszertani hátterét egy 1973-as Fama-MacBeth-írás adja. Röviden érdemes a tanulmány legfontosabb módszertani üzeneteit összefoglalni, annál is inkább, mert számos későbbi elemzés is támaszkodik erre a technikára; többek között a bemutatásra kerülő Chen et al. (1986:394) cikk is. Első lépésben a kiválasztott részvények hozamait kell magyarázni a kiválasztott kockázati faktorokkal, hogy eredményül a kockázati faktorokhoz kapcsolódó béta paramétert kapjuk. A második lépésben szintén a hozamokat kell regresszálni, de ezúttal az első lépésben kapott bétákkal. A második regresszió eredménye a faktorok kockázati prémiuma.
} 
befektetések teljesítettek jobban, értek el magasabb hozamot. A második - nagyobb felzúdulást keltő - következtetésük úgy szólt, hogy a szisztematikus kockázat, azaz a béta és a hozamok között nincs kapcsolat (a béta statisztikailag nem szignifikáns). A CAPM alkalmazhatóságát tekintve ez aggasztó hír volt.

Fama és French pár évvel későbbi publikációjában (1996) a háromfaktoros modellként elhíresült eszközárazási technikáját ismertette meg a tudományos közösséggel. A tanulmány címe (Multifactor Explanation of Asset Pricing Anomalies) sokatmondó abban a tekintetben is, hogy azokra a kockázattal korrigált hozamprémiumokra keresték a magyarázatot, amelyek a CAPM szempontjából nem értelmezhetőek. Megítélésük szerint a piaci portfólión túl két további magyarázó változóval megragadhatók a tapasztalt anomáliák: a kis és nagy kapitalizációjú vállalatokból képzett portfóliók hozamának különbségével (méretfaktor, SMB), továbbá a magas és alacsony BV/P értékkel rendelkező részvényekből képezett portfóliók hozamkülönbözetével (value-faktor, $\mathrm{HML}$ ).

A szerzők a közelmúltban (Fama - French 2015) kiegészítették korábbi modelljüket további két faktorral, nevezetesen a jövedelmezőségi (hivatkozva Novy-Marxra 2013) és beruházási változóval. A változók definiálásánál a háromfaktoros modellben alkalmazott megközelítést követték. A jövedelmezőségi változót a robusztus és gyenge múködési eredménnyel rendelkező vállalatokból képzett diverzifikált portfóliók hozamkülönbözete képviselte (RMW). A beruházási változót (CMA) a konzervatív és agresszív beruházási politikát folytató vállalatokból képzett portfóliók hozamkülönbözete reprezentálta.

\section{Tiszta faktorportfóliók a szakirodalomban}

A közelmúltban publikált több tanulmány (Menchero 2010; Menchero - Lee 2015; Clarke et al. 2017; Menchero - Ji 2017) is felhívta a figyelmet a korábbi hozammagyarázó modellek statisztikai hiányosságaira. Az idézett publikációk a tiszta faktorportfóliók (pure factor portfolios) jelentőségét emelik ki. A tiszta faktorok előnye, hogy nem érvényesülnek bennük más faktoroknak a hatásai, azaz a tiszta faktorok a legjobban korrelálnak az adott faktorral, de nem korrelálnak a többivel (kiküszöbölik a multikollinearitást). Matematikailag a tiszta faktorportfóliók többváltozós keresztmetszeti regresszión alapulnak. Clarke et al. (2017:27) alapján: „...a tiszta faktorportfóliókat rendszeres időközönként újrasúlyozzák oly módon, hogy az elemzett faktoron kívül minden más faktorral szemben zéró legyen a kitettségük. Az egyes értékpapírok tiszta faktorportfólión belüli súlya a többváltozós Fama-MacBeth-féle (1973) regresszión alapul." 
A tiszta faktorok definíciója egybecseng a többfaktoros APT-modelleknél megismert és a modellezés során elvártnak tekintett meghatározással. Bodie et al. (2011:331) faktorportfóliókra vonatkozó definícióját alapul véve ${ }^{10}:$, „...egy olyan jól diverzifikált portfólió, amelyet úgy hoztak létre, hogy az egyik faktorra vonatkoztatott bétája egy, de zéró bármely más faktorra vetítve. Úgy is gondolhatunk a faktorportfólióra, mint egy követő portfólióra (tracking portfolio)."

Menchero - Lee (2015:71-72) a faktorportfóliókat három nagyobb csoportba sorolja: (1) egyszerű faktorportfóliók, amelyeket egyváltozós regresszióval lehet módszertanilag megragadni; (2) tiszta faktorportfóliók, amelyeknél a többváltozós regressziók alkalmazása az üdvözítő megoldás; (3) minimum-volatilitás faktorportfóliók, amelyek várható hozam-variancia optimalizáláson alapulnak. A következőkben a hangsúly a tiszta faktorportfóliókon (2) lesz, de előtte röviden összefoglaljuk az egyszerű faktorportfóliók hiányosságait, ezáltal érzékelhető lesz, hogy miképpen érnek el a tiszta faktorok érdemi javulást.

Az egyszerű faktorportfólióknak leginkább az a hátulütőjük, hogy más faktorok véletlenszerú hatásai is jelentkezhetnek bennük, oly módon, hogy szükségtelen kockázatot visznek a portfólióba, de anélkül, hogy javítanák a várható teljesítményt. Menchero - Lee (2015:73) a következő példákkal szemlélteti a torzító hatást: ha a pozitív momentummal rendelkező részvényekre egyszerre jellemző a magasabb béta is, akkor a momentumfaktor pozitív kitettséggel rendelkezik a béta faktorral szemben. Hasonlóan, amennyiben az energetikai részvények az utóbbi időben jól teljesítettek, akkor az egyszerú momentumfaktor felülsúlyozza az energiaszektort (a benchmarkhoz képest). Egyszerübben fogalmazva: nem a valódi nagyságú kockázat-hozam relációt mutatják.

A tiszta faktorok alkalmazásával kezelhetővé válik a multikollinearitás, köszönhetően a többváltozós regressziós modelleknek. Menchero - Ji (2017) példaként a Bloomberg Global Equity Modelljét említi, amelynél az egyes tiszta faktorhozamokat a részvényhozamok négyféle alapfaktorral szembeni regressziója alapján kalkulálják. Ezek a következők: piac- ( $\mathrm{M}$ - market), ország- (c - country), iparág- ( $\mathrm{i}$ - industry), és befektetési stílus- (s - styles) faktorok. Képletszerüen:

$$
r_{n}=r_{M}+\sum_{c} X_{n c} r_{c}+\sum_{i} X_{n i} r_{i}+\sum_{s} X_{n s} r_{s}+u_{n}
$$

\footnotetext{
${ }^{10}$ A faktorportfóliókról és azok hozamot meghatározó szerepéről lásd még például Lovas (2017).
} 
A fenti egyenletben ",$r_{n}$ ” az adott $n$ részvény várható hozama, „, $r_{M}$ ” a piaci faktor várható hozama, „, $\mathrm{X}_{\mathrm{nc}}$ ” az adott $\mathrm{n}$ részvény adott c országfaktornak való kitettsége, és " $r_{c}$ " az adott c országfaktor várható hozama ${ }^{11}$. Hasonlóan értelmezhetőek a további faktorok is: „ $X_{n i}$ " és „ $r_{i}$ " rendre az i iparágnak való kitettség és várható hozam, míg " $\mathrm{X}_{\mathrm{ns}}$ " és " $\mathrm{r}_{\mathrm{s}}$ " az adott $\mathrm{s}$ stílussal szembeni kitettség és várható hozam. $\mathrm{Az}$ „ $\mathrm{u}_{\mathrm{n}}$ ” az adott $\mathrm{n}$ részvény idioszinkratikus hozama. Az egyes részvényspecifikus hozamokról feltesszük, hogy egymással és az egyes faktorokkal nem korrelálnak.

$A z$ (1) egyenletből látható, hogy a részvények piaci faktorra vonatkoztatott kitettsége egységnyi. Az ország- és iparágfaktoroknak való kitettséget dummy változókkal mérjük, azaz az adott részvény egységnyi kitettséggel rendelkezik a saját országának és iparágának, de zéró kitettséggel minden más országnak és iparágnak. A stílusfaktoroknak való kitettséget az adott faktor (például P/E) standardizált értékeivel lehet mérni. A standardizálás eredményeként, amennyiben a részvény megfelelő stílusfaktorra vonatkoztatott kitettsége pozitiv, akkor az adott részvény adott stílust tekintve átlag feletti értékkel bír.

Menchero és Ji (2017) a tiszta faktorok múködési logikájára egy példát is bemutat, a Bloomberg Global Equity Modell 2016. január 31-i adatait felhasználva. Az 1. táblázat különféle faktorportfóliók súlyozását tartalmazza, a globális részvénypiacok különféle szegmenseit érintve ${ }^{12}$. Kiegészítésként a (globális) piaci portfólió súlyarányait is feltüntetik a táblázat második oszlopában.

\footnotetext{
${ }^{11}$ Gyakran félreértésekre adhat okot, hogy a faktormodellezés során a „faktorra” való hivatkozáskor mire is gondolunk pontosan. Célszerű hangsúlyozni a faktorkitettség és a faktorhozam közötti különbséget. A faktorkitettség az egyedi részvények sokszor értelemszerű tulajdonságait öleli fel: adott iparághoz, országhoz való tartozást. Ezzel szemben a faktorhozam az a hozam, amely az elemzett faktorkitettségből származtatható (megfelelő matematikai apparátust használva).

${ }^{12}$ A táblázat kivonatos, vagyis nem szerepel benne valamennyi ország-, iparág- és befektetésistílus-faktor.
} 


\section{1. táblázat}

A Bloomberg Global Equity Modell 2016. január 31-én

\begin{tabular}{l|c|c|c|c|c|c}
\multicolumn{1}{c|}{ Piaci szegmens } & $\begin{array}{c}\text { Piaci } \\
\text { portfólió }\end{array}$ & $\begin{array}{c}\text { Piaci } \\
\text { faktor }\end{array}$ & $\begin{array}{c}\text { USA } \\
\text { faktor }\end{array}$ & $\begin{array}{c}\text { Japán } \\
\text { faktor }\end{array}$ & $\begin{array}{c}\text { Autó } \\
\text { faktor }\end{array}$ & $\begin{array}{c}\text { Value } \\
\text { faktor }\end{array}$ \\
\hline Világ (nettó) & $100,00 \%$ & $100,00 \%$ & $0,00 \%$ & $0,00 \%$ & $0,00 \%$ & $0,00 \%$ \\
Long & $100,00 \%$ & $105,19 \%$ & $61,25 \%$ & $93,46 \%$ & $108,69 \%$ & $40,18 \%$ \\
Short & $0,00 \%$ & $-5,19 \%$ & $-61,25 \%$ & $-93,46 \%$ & $-108,69 \%$ & $-40,18 \%$ \\
\hline USA (nettó) & $39,55 \%$ & $39,55 \%$ & $60,45 \%$ & $-39,55 \%$ & $0,00 \%$ & $0,00 \%$ \\
Long & $39,55 \%$ & $39,65 \%$ & $60,45 \%$ & $0,07 \%$ & $15,75 \%$ & $9,52 \%$ \\
Short & $0,00 \%$ & $-0,09 \%$ & $0,00 \%$ & $-39,62 \%$ & $-15,75 \%$ & $-9,52 \%$ \\
\hline Japán (nettó) & $8,36 \%$ & $8,36 \%$ & $-8,36 \%$ & $91,64 \%$ & $0,00 \%$ & $0,00 \%$ \\
Long & $8,36 \%$ & $9,32 \%$ & $0,02 \%$ & $91,64 \%$ & $26,25 \%$ & $4,42 \%$ \\
Short & $0,00 \%$ & $-0,97 \%$ & $-8,38 \%$ & $0,00 \%$ & $-26,25 \%$ & $-4,42 \%$ \\
\hline Autóipar (nettó) & $2,93 \%$ & $2,93 \%$ & $0,00 \%$ & $0,00 \%$ & $97,07 \%$ & $0,00 \%$ \\
Long & $2,93 \%$ & $3,11 \%$ & $0,98 \%$ & $4,94 \%$ & $97,07 \%$ & $1,24 \%$ \\
Short & $0,00 \%$ & $-0,18 \%$ & $-0,98 \%$ & $-4,94 \%$ & $0,00 \%$ & $-1,24 \%$ \\
\hline USA autóipar (nettó) & $0,38 \%$ & $0,43 \%$ & $0,87 \%$ & $-0,97 \%$ & $11,98 \%$ & $0,10 \%$ \\
Long & $0,38 \%$ & $0,43 \%$ & $0,87 \%$ & $0,00 \%$ & $11,98 \%$ & $0,18 \%$ \\
Short & $0,00 \%$ & $0,00 \%$ & $0,00 \%$ & $-0,97 \%$ & $0,00 \%$ & $-0,08 \%$ \\
\hline Japán autóipar (nettó) & $0,99 \%$ & $0,89 \%$ & $-0,19 \%$ & $4,94 \%$ & $26,25 \%$ & $0,09 \%$ \\
Long & $0,99 \%$ & $0,94 \%$ & $0,01 \%$ & $4,94 \%$ & $26,25 \%$ & $0,33 \%$ \\
Short & $0,00 \%$ & $-0,04 \%$ & $-0,20 \%$ & $0,00 \%$ & $0,00 \%$ & $-0,23 \%$ \\
\hline
\end{tabular}

Forrás: Menchero - Ji (2017:6)

A táblázat harmadik oszlopából kiolvasható, hogy a piaci faktorportfólió 100 százalékban nettó long pozíciót tartalmaz. A többi faktorportfólió szigorúan dollársemleges. A japán faktorportfólió 100 százalékban long a japán piacot tekintve, és 100 százalékban short a piaci portfóliót tekintve. Mindenesetre a piaci portfólión belül a japán piac nettó 8,36 százalékos részt képvisel, ezért a két pozíció értékeit összevezetve 91,46 százalékos long nettó súly adódik a japán piacra (ezzel analóg módon 91,46 százalékos short nettó súlya van minden más piacnak). A japán faktorportfólió iparágsemleges, azaz nulla nettó súly szerepel minden iparágnál (ebben a táblázatban csupán az autóipar került bemutatásra). Ugyanígy elmondható, hogy a japán faktor stílussemleges (ezt azonban a táblázat nem tartalmazza).

Az iparági tiszta faktorportfóliók hasonló módon interpretálhatók: 100 százalékban hosszú pozíciót vesznek fel az adott iparágban (autóipar), és ugyancsak 100 százalékban rövid pozíciót a piaci portfólióban. Minthogy jelen esetben a piaci portfólióban az autóipar súlya 2,93 százalék, ezért összességében 97,07 százalékos long nettó súly adódik az autóiparra (ezzel párhuzamosan 97,07 százalékos short nettó súly minden más iparágra). Az iparágfaktor ország és befektetésistílus-semleges. 
Gyakorlati példaként tételezzünk fel egy globális portfólióbefektetőt (Menchero - Ji 2017:7), aki a japán piacra (is) szeretne befektetni (alapvetően erősödést vár), de nem szeretne elköteleződni sem befektetési stílus, sem iparág, és semmiféle egyéb változó alapján sem, csupán az országfaktor számít. Amennyiben a befektető a japán piaci portfóliót vásárolná meg, akkor a portfólión belül az autóipar részaránya 11,84 százalék lenne ${ }^{13}$, szemben a globális portfólió 2,93 százalékával, vagyis felülsúlyozná az autóipart. A tiszta faktorportfóliók azonban kiküszöbölik ezt a hibát azáltal, hogy megfelelően szétválogatják a hozamok valódi forrásait. Másképpen fogalmazva: a globális piaci portfólió és a tiszta japán országfaktor-portfólió megvásárlásával egy olyan portfóliót kapunk, amely 100 százalékban hosszú pozíciót vesz fel japán befektetésekben, zéró nettó súlyt más országokban, iparágsemleges, befektetésistílus-semleges.

Clarke és szerzőtársai (2017) tanulmányukban 1000 egyesült államokbeli tőzsdei részvénytársaság 1967 és 2016 közötti havi hozamait vizsgálták hat különböző faktor vonatkozásában: 1) value (E/P); 2) momentum; 3) méret; 4) alacsony volatilitás (alacsony béta); 5) jövedelmezőség; 6) kötvény béta. Ez utóbbi a piaci kamatok részvénypiacokra és a felsorolt faktorokra vonatkozó hatásait hivatott vizsgálni. A tanulmány elsődleges üzenete módszertani abban az értelemben, hogy a szerzők felhívják a figyelmet a tiszta faktorok használatának a szükségességére. Érvelésük alapján a Fama-MacBeth regressziós keretrendszer abban az esetben múködhet igazán megfelelően, ha az egyes magyarázó faktorokat rendszeresen megtisztítják a másodlagos hatásoktól. Nem céljuk új faktorok azonosítása, azonban az 50 évnyi adat érdekes eredményeket rejt magában. Ezek egyike, hogy az utóbbi 15 évben a tiszta értékfaktor piaci hozam feletti prémiuma eltűnőben van. A momentumfaktornál hasonló fejleményeket lehet megfigyelni azt követően, hogy a '90-es években egyre elterjedtebb lett az alkalmazásuk.

\section{Faktorportfóliók módszertani keretrendszere ${ }^{14}$}

A faktorhozamok számszerűsítése legtöbbször keresztmetszeti regressziók alkalmazásával történik. Az adott faktort faktorimitáló portfólióval reprezentáljuk. Kétféleképpen lehet faktorimitáló portfóliókat összeállítani: 1) egyszerü faktorportfóliókat egyváltozós regressziók alapján, 2) tiszta faktorportfóliókat többváltozós regressziók alapján. Az egyszerű faktorportfóliók hiányosságaira korábban már utaltunk, azonban módszertani szempontból mégis fontos kiindulópontot jelentenek. Az alábbiakban először bemutatjuk a befektetési stílusokhoz, majd az ország- vagy

\footnotetext{
${ }^{13}$ A globális portfólión belül a japán autóipar 0,99 százalékos piaci aránnyal rendelkezik, a teljes japán piac pedig 8,36 százalékkal. A kettő hányadosa 11,84 százalék.

14 Jelen módszertani levezetés Menchero (2010), Mechero - Ji (2017) és Clarke et al. (2017) munkáira támaszkodik.
} 
iparágfaktorokhoz ${ }^{15}$ kapcsolódó faktorhozamok egyváltozós regressziós számítási metodikáját. Az egyváltozós eset után röviden áttérünk a többváltozós regressziókra.

A befektetési stílusokra vonatkozó egyszerű faktorok hozamára egyváltozós regressziót vázolunk fel:

$$
r_{n}=r_{w}+X_{n s} r_{s}+u_{n}
$$

ahol ", $r_{n}$ ” az adott $n$ részvény várható hozama, ", $r_{\mathrm{W}}$ ” a tengelymetszet, ", $\mathrm{X}_{\mathrm{ns}}$ ” az adott $\mathrm{n}$ részvény adott $\mathrm{s}$ stílusnak való kitettsége, " $\mathrm{r}_{\mathrm{s}}$ ” az adott $\mathrm{s}$ stílusfaktor hozama, $a z ~ " u_{n}$ ” pedig a vállalatspecifikus hozam. Minden részvény egységnyi kitettséggel rendelkezik a tengelymetszettel szemben, amit világfaktornak ${ }^{16}$ nevezhetünk. A faktorhozamokat $\left(r_{s}\right)$ kellően nagy elemszámú mintán kell becsülni.

A faktorhozamok becslési hibájának a csökkentéséért megfelelő súlyozást kell alkalmazni. Az egyik lehetséges (de nem kizárólagos) számítási mód a részvények kapitalizációjának négyzetgyökét alkalmazza:

$$
\Sigma_{n} v_{n}=1
$$

ahol „, $\mathrm{V}_{\mathrm{n}}$ " az adott $\mathrm{n}$ részvény kapitalizációjának a négyzetgyöke, arányosítva a vizsgált befektetési univerzum teljes kapitalizációjának a gyökével. Összegezve a részarányokat 1-et kapunk.

Minthogy az adott s befektetési stílusnak való kitettségértékek standardizáltak, ezért a regressziós súlyokkal kalkulált várható érték nulla:

$$
\Sigma_{n} v_{n} X_{n s}=0 .
$$

A standardizálás eredménye, hogy az adott faktor regressziós súlyokkal számított szórása egységnyi:

$$
\Sigma_{n} v_{n} X_{n s}^{2}=1 .
$$

Felhasználva az eddigi összefüggéseket, a stílusfaktor hozamára a következő öszszefüggést tudjuk felírni:

$$
r_{s}=\Sigma_{n}\left(v_{n} X_{n s}\right) r_{n},
$$

ahol " $\mathrm{r}_{\mathrm{s}}$ ” a faktorportfólió hozama " $\mathrm{v}_{\mathrm{n}} \mathrm{X}_{\mathrm{ns}}$ ” súly mellett. Gyakorlati oldalról megközelítve az összefüggést, az egyszerű stílusfaktor-portfólió hosszú pozíciót vesz fel a pozitív kitettséggel, és rövid pozíciót a negatív kitettséggel rendelkező részvényekből, azzal, hogy arányosan nagyobb pozíciót alakít ki a nagyobb regressziós

\footnotetext{
${ }^{15}$ Módszertani szempontból tehát különbséget teszünk a folytonos skálán mért (jellemzően standardizált) és a dummy változókkal reprezentált faktorok között.

${ }^{16}$ Globális befektetőt feltételezve.
} 
súllyal bíró részvényekből. A portfólió dollársemleges, hiszen a súlyok összege 0 . A stílusfaktor-portfólió adott stílusnak való kitettsége egységnyi $\left(a v_{n} x_{n s}\right.$ súlyok és az $\mathrm{X}_{\mathrm{ns}}$ kitettség szorzatösszege 1 ).

A dummy változókkal mért csoportképző faktorok regressziós egyenlete a következő:

$$
r_{n}=r_{w}+\Sigma_{g} X_{n g} r_{g}+u_{n},
$$

ahol „ $X_{n g}$ ” az adott $n$ részvény g csoportképző faktornak való kitettségét $(0,1)$ méri, " $\mathrm{r}_{\mathrm{g}}$ " az adott g csoportképző faktorra vonatkoztatott faktorhozam. A többi változó értelmezése a (2) képlethez hasonló.

A (7) képlet egyértelmú multikollinearitást tartalmaz (az iparágak összessége megegyezik a világ portfólióval), ezért a regresszió további használhatósága érdekében a következő korlátozást vezetjük be:

$$
\Sigma_{g} W_{g} r_{g}=0 .
$$

A képlet értelmében a piaci értéksúlyozású faktorhozamok összege $0\left(\right.$, $\mathrm{W}_{\mathrm{g}}{ }^{\prime \prime}$ az adott csoport piaci súlyát jelenti). A (8) összefüggést felhasználva az egyszerú világfaktor hozamára a (9) formula alkalmazható:

$$
r_{W}=\Sigma_{g} W_{g} \Sigma_{n \in g}\left(\frac{v_{n} r_{n}}{V_{g}}\right),
$$

ahol „, $\mathrm{V}_{\mathrm{g}}{ }$ az adott $\mathrm{g}$ csoport regressziós súlya.

A dummy változókkal mért faktorok esetében a világfaktor csak hosszú pozíciót tartalmaz. Minden csoport piaci érték súlyozású, azonban adott csoporton belül az egyes részvények súlyozására a regressziós súlyokat alkalmazzuk. Az egyszerú csoportképző faktorhozamokra alkalmazható képlet az alábbi:

$$
r_{g}=\frac{1}{V_{g}} \Sigma_{n \in g}\left(v_{n} r_{n}\right)-r_{w},
$$

ahol „r $r_{W}$ ” a (9) képlet alapján értelmezhető. A (10) képlet tartalmára egy példa: az egyszerű országfaktor-portfóliók hosszú pozíciót vesznek fel a regressziós súlyokat alkalmazó országportfólióban és rövid pozíciót a világportfólióban.

A tiszta faktorportfóliók kialakításához többváltozós regressziós számításokat kell alkalmazni. Megismételhetjük az (1) képletet:

$$
r_{n}=r_{w}+\sum_{c} X_{n c} r_{c}+\sum_{i} X_{n i} r_{i}+\sum_{s} X_{n s} r_{s}+u_{n} .
$$

A modell regressziós súlyként az adott részvények piaci kapitalizációjának négyzetgyökével arányos súlyokat alkalmaz. Minden részvény egységnyi kitettséggel rendelkezik a világ portfólióval, és a hozzá tartozó ország-, iparág- és befektetésistílus-portfólióval szemben (minden más esetben zéró a kitettség). Az idioszinkratikus 
hozamok egymással és a faktorokkal korrelálatlanok. A modell a korábban bemutatottak szerint kezeli a multikollinearitás problémáját. Menchero (2010), hivatkozva Ruud (2000) munkájára, az egyes faktorhozamokat - a súlyozott legkisebb négyzetek módszerét felhasználva (WLS) - a következőképpen írja le:

$$
r_{k}=\Sigma_{n} \Omega_{n k} r_{n},
$$

ahol „ $\Omega_{\mathrm{nk}}{ }^{\prime}$ az adott $\mathrm{n}$ részvény adott $\mathrm{k}$ tiszta faktorportfólión belüli súlyát jelenti.

\section{Az empirikus elemzés módszertana, a felhasznált adatbázis}

Tanulmányunk empirikus részében összevetjük az egyes faktorok és a piaci portfólió teljesítményét, így több, fontos módszertani kérdés is felmerül: melyek a szakirodalomban és a befektetési szakmában leginkább elterjedt teljesítménymércék? Milyen statisztikai-matematikai eszköztár és feltételezések szükségesek a teljesítménymércék helyes számításához? A következő bekezdésekben e kérdésekre keressük a választ.

A befektetések teljesítményének mérésére számos mutató áll rendelkezésre: Eling és Schuhmacher (2007), valamint Farinelli et al. (2008) publikációi kiváló összefoglalását adják a témának. Tanulmányunknak nem célja a teljesítménymutatók univerzumának teljes feltérképezése, mindenesetre kiválasztottunk két, széleskörüen használt mutatót, a Jensen-féle alfát és a Sharpe-rátát. Az alfával arra keressük a választ, hogy az adott faktor túlteljesítette-e a piaci portfóliót, vagy sem. A Sharperáta szintén a többlethozamot méri, de már figyelembe veszi a teljes kockázatot.

Michael C. Jensen (1968) alfa mutatója a CAPM-hez képest mért többlethozamot mutatja. Számításának menete a következő:

$$
\text { Alfa }_{i t}=r_{i t}-\left(r_{f t}+\beta_{i} \cdot\left(r_{M t}-r_{f t}\right)\right),
$$

ahol „, $\mathrm{r}_{\mathrm{it}}$ " az adott i faktor hozama, „, $\mathrm{r}_{\mathrm{ft}}$ " a kockázatmentes hozam, „, $\beta_{\mathrm{i}}$ " a piaci kockázati mérték és ", $r_{\mathrm{Mt}}-r_{\mathrm{ft}}$ " a piaci kockázati prémium adott $\mathrm{t}$ időpontra. A béta az alábbi összefüggés alapján adódik:

$$
\beta_{i}=\frac{\operatorname{Cov}_{i M}}{\operatorname{Var}_{M}},
$$

ahol a "Covim” az adott i faktor és a piaci portfólió (M) hozamai közötti kovariancia, és „ $\operatorname{Var}_{M}$ ” a piaci portfólió hozamának varianciája. 
A Sharpe-mutatót William F. Sharpe ismertette 1966-os tanulmányában ${ }^{17}$. Számításakor megvizsgáljuk, hogy az adott portfólió kockázatmentes hozamon felüli prémiuma miképpen aránylik a teljes kockázathoz:

$$
\text { Sharpe }_{i t}=\frac{r_{i t}-r_{f t}}{\sigma_{i t}}
$$

ahol „ $r_{i t}-r_{f t}$ ” az adott i faktorportfólió kockázatmentes befektetésen felüli hozamprémiuma adott $\mathrm{t}$ időpontban, „ $\sigma_{i t}$ ” pedig az adott i faktorportfólió $\mathrm{t}$ időpontbeli kockázati hozamprémiumának szórása.

A többlethozam tesztelésére regressziós modelleket fogunk alkalmazni. A koncepciónk lényege, hogy először egyenként megmagyarázzuk az egyes tiszta faktorok teljesítményét (függő változók) a piaci portfólió teljesítményével (magyarázó változó). Elemzésünk szempontjából a regressziós egyenletek konstans paramétere $\left(\beta_{0}\right)$ lesz döntő jelentőségű: amennyiben értéke szignifikánsan eltér nullától, elmondhatjuk, hogy az adott faktor többlethozamot biztosít. A regressziós egyenleteket a következő tartalommal töltjük fel: a magyarázó változók rendre a piaci portfólió loghozama és Sharpe-rátája, az eredményváltozók pedig az adott faktor loghozama és Sharpe-rátája lesznek.

A teljesítménymércék teszteléséhez szükséges még specifikálni a regressziók típusát. Ezt a kérdést alapjaiban határozza meg a hozamok és a Sharpe-ráta idősorát jellemző hibatagok viselkedése: ha a hibatagok homoszkedasztikusak és autokorrelálatlanok, akkor egyszerü OLS-regressziót alkalmazhatunk ${ }^{18}$. Amennyiben a fenti elvárások nem teljesülnek, akkor a pénzügyi idősorok elemzésre megalkotott $A R C H-G A R C H$ alapú regressziós modelleket használhatjuk. Az autokorreláció tesztelésére Engle ún. ARCH-hatások (ARCS effects) tesztjét fogjuk alkalmazni, a heteroszkedaszticitás zavaró jelenségére pedig a Breusch-Pagan-tesztet.

Fontosnak tarjuk hangsúlyozni, hogy a GARCH-modellek alkalmazására akkor is sort kerítünk, ha az adott regressziós eljárás végül OLS alapú lesz, hiszen a Sharpe-ráta nevezőjében szereplő volatilitás vagy a Jensen-féle alfa-számításhoz szükséges béta paraméter időben nem állandó, vagyis feltételes varianciák-kovarianciák használata válik szükségessé. A GARCH-modellek jelentősége tehát abban áll, hogy dinamizálják a volatilitást és a kovarianciákat, amelyek így hozzájárulnak ahhoz, hogy a teljesítménymutatók is dinamikussá, a hipotéziseink pedig érdemben tesztelhetővé váljanak. Az elemzés során egyszerü GARCH- és DCC GARCH-modelleket fogunk

\footnotetext{
${ }^{17}$ Sharpe eredetileg „reward-to-variability” aránynak nevezte el az összefüggést, csak később, az ő tiszteletére terjedt el a Sharpe-ráta elnevezés.

${ }^{18}$ Vannak további elvárások is az OLS regressziós modellekre vonatkozóan, amelyek nélkül a legkisebb négyzetek módszere nem lehet BLUE (legjobb lineáris torzítatlan becslő eljárás). Ezekről bővebben lásd például Wooldridge (2013) munkáját.
} 
tehát alkalmazni, amelyek módszertani háttere megtalálható Bollerslev (1986) és Engle (1982; 2002) publikációiban.

A faktorhozamok teljesítményének teszteléséhez megbízható adatokra is szükségünk volt. A faktorportfóliók és a piaci index hozamadatainak forrása a Bloomberg adatbázisa. A letöltött idősorok az elmúlt közel két évtizedet ölelik fel, azaz a 2000. január 4. és a 2018. december 10. közötti időszak heti loghozamait tartalmazzák az Egyesült Államok részvénypiacaira vonatkozóan. A heti loghozamok a piaci portfólió és tíz tiszta faktorportfólió hozamadatai. A Bloomberg Factors to Watch (FTW), Pure Factor Returns funkciójának segítségével heti szinten súlyozzuk újra a tiszta faktorportfóliókat. Az elemzésbe a 2. táblázatban felsorolt 10 tiszta faktorportfóliót vontuk be.

\section{2. táblázat}

Az empirikus elemzés során vizsgált tiszta faktorportfóliók

\begin{tabular}{l|c|c|c}
\multicolumn{1}{c|}{ Elnevezés } & Rövidítés & Elnevezés & Rövidítés \\
\hline Érték (value) & E & Volatilitás (volatility) & Vol \\
\hline Méret (size) & M & Osztalék (dividend) & O \\
\hline Profitabilitás, jövedelmezőség (profitability) & P & Növekedés (growth) & $\mathrm{N}$ \\
\hline Kereskedési aktivitás (trade activity) & KA & Tőkeáttétel (leverage) & T \\
\hline Eredmény változékonysága (earnings variability) & EV & Momentum & Mom \\
\hline
\end{tabular}

A táblázatban szereplő méretfaktor nagyvállalati fókuszú. Amennyiben megfordítjuk az irányt, akkor a méretfaktor a kisvállalatok teljesítményét reprezentálja, vagyis a teljesítményre vonatkozó előjelek is megfordulnak. Az empirikus elemzésnél erre a modellsajátosságra ügyelni fogunk. A választásunk azért esett e faktorokra, mert a vonatkozó kutatások leginkább ezekre a befektetési stílusokra fókuszálnak, ahogyan azt a szakirodalom áttekintésénél már bizonyítottuk ${ }^{19}$.

Az elemzés során benchmarknak tekintett piaci portfólió a piaciérték-súlyozású Russell 3000 Index, amely magában foglalja az Egyesült Államok 3000 legnagyobb kapitalizációjú, tőzsdén jegyzett vállalatát. Az indexben szereplő vállalatok hozzávetőlegesen lefedik a teljes amerikai részvénypiac 98 százalékát. Az 1. ábra a Russell 3000 Index 2000 és 2018 közötti árfolyamát ábrázolja.

\footnotetext{
${ }^{19}$ A tiszta faktorportfóliók Bloomberg által alkalmazott definícióit és számításuk módját cikkünk mellékletében ismertetjük.
} 


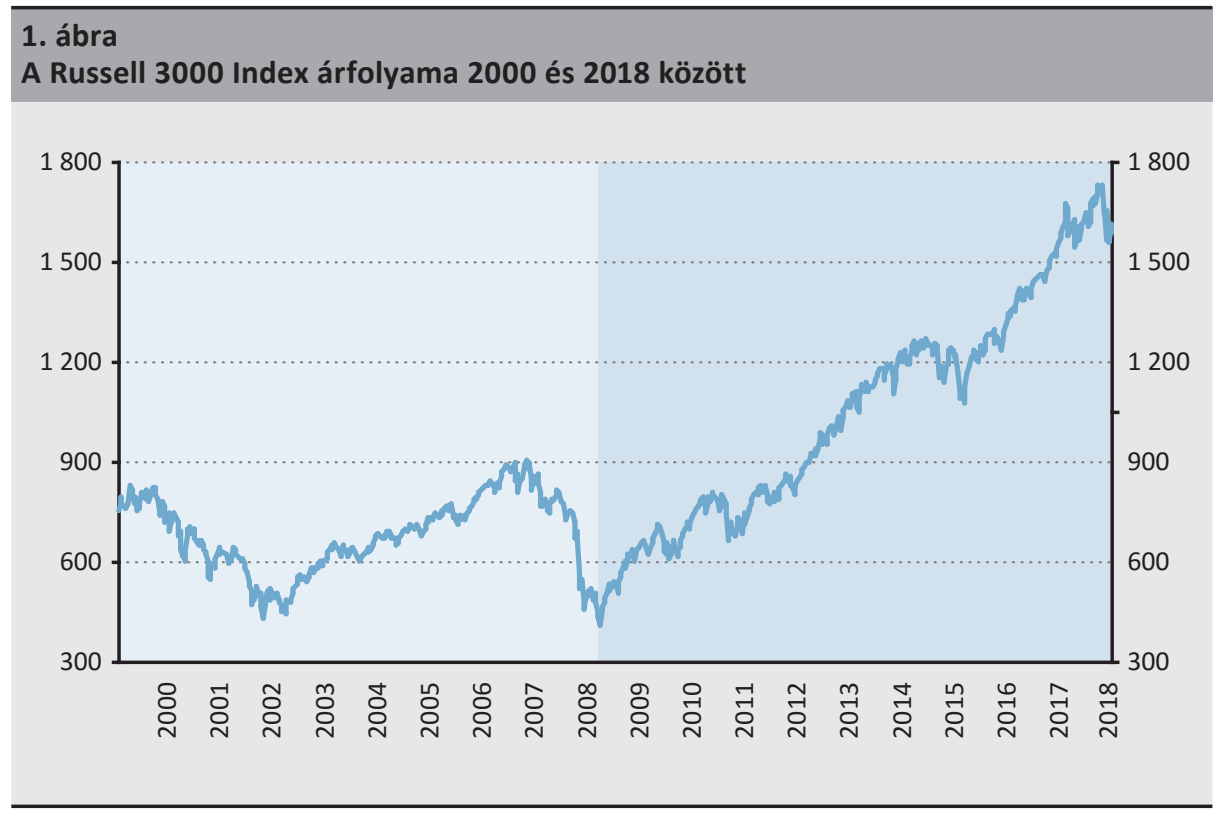

Az ábrán megkülönböztettünk két időszakot. Az első 2000 elejétől 2009 első negyedévéig terjed, és „válságos időszakként” hivatkozunk rá. Az új évezred elején pukkant ki a dotcom-lufi, majd 2007-ben kezdődött az Egyesült Államokban a másodlagos jelzáloghitel-válság, amely gyorsan világméretú gazdasági válsággá terebélyesedett. 2009 márciusára a piac elérte a mélypontját, amelyet kisebb-nagyobb megingásokkal, de egy lényegében 10 évet felölelő fellendülés követett. A 2009 márciusát követő időszakra tehát mint a „fellendülés” éveire tekintünk.

Természetesen részletesebben is meg lehetne bontani az idősort. Az általunk válságosnak titulált időszakban 2002 és 2007 között korrekció volt tapasztalható. A 2009 és 2018 közötti fellendülés során 2010 körül bontakozott ki többek között a görög adósságválság; 2014 és 2016 között az olajárak jelentősen csökkentek, ami magával hozta az orosz pénzügyi krízist. A jelen tanulmány elemzési céljainak megfelelően és terjedelmi korlátok miatt azonban elégséges, ha csupán ezt a két nagyobb időszakot különítjük el, hogy az egyes faktorok teljesítményét a teljes időszakra vonatkoztatott elemzésen túl, különféle „árfolyamrezsimek” mellett is megvizsgáljuk, vagyis teszteljük, hogy van-e különbség az egyes faktorok teljesítményében „válság” alatt (2000-2009 eleje) és a „fellendülés” éveiben.

Mielőtt az empirikus eredményeinkre áttérünk, megvizsgáljuk, hogy teljesülnek-e a GARCH- és a DCC GARCH regressziós modellek alkalmazhatóságának a feltételei. Először a tiszta faktorportfóliók és a piaci index loghozamait vizsgáljuk, hiszen ezek az adatok jelentik a Jensen-féle alfa számításának az input-adatait, továbbá a Sharpe-mutató nevezőjében szereplő volatilitások számításához is szeretnénk 
a GARCH-modellt felhasználni ${ }^{20}$. A loghozamokat követően megvizsgáljuk a GARCH alapú regressziók viselkedését a Sharpe-ráták idősorainál is.

A 2. ábrán a Russell 3000 Index és a 10 tiszta faktorportfólió heti loghozamai láthatók 2000 és 2018 között. A loghozamok alapján intuitíven vizsgálhatjuk a volatilitás klasztereződését. A legtöbb faktor esetében egyértelműen megfigyelhető a volatilitás csoportosulása (sötétebb háttérszínnel jelöltük a két jelentősebb válságot). A vizsgált időszak elején, 2000 és 2002 között jellemző volt a hozamok erőteljes ingadozása (dotcom-lufi), amelyet nyugodtabb időszak követett, majd 2008-ban és 2009-ben ismét rendkívüli volatilitásnak lehettünk a tanúi (gazdasági világválság). Az elmúlt közel egy évtizedben újból csendesebb évek köszöntöttek be.

Amennyiben formalizáltabb keretek között szeretnénk megvizsgálni a GARCH-modellek alkalmazhatóságát, célszerű lehet elvégezni Engle Lagrange multiplikátor-tesztjét (ARCH-hatások teszt). A teszteredményeket foglalja össze a 3. táblázat.

\section{3. táblázat}

Heti loghozamok és Sharpe-ráták Engle-féle ARCH-hatás-tesztje

(3 heti késleltetés)

\begin{tabular}{|c|c|c|c|c|c|c|c|c|c|c|c|}
\hline$L M$ & $R X$ & $E$ & $M$ & $P$ & $K A$ & $E V$ & Vol & 0 & $N$ & $T$ & Mom \\
\hline \multicolumn{5}{|l|}{$\mathrm{H}_{0}$} & \multicolumn{7}{|c|}{ Nincs ARCH-hatás } \\
\hline \multicolumn{5}{|l|}{$\mathrm{H}_{\mathrm{A}}$} & \multicolumn{7}{|c|}{ Van ARCH-hatás } \\
\hline \multicolumn{12}{|c|}{ Loghozamok } \\
\hline$\chi^{2}$ & $\begin{array}{c}57,94 \\
* * *\end{array}$ & $\begin{array}{c}65,86 \\
* * *\end{array}$ & $\begin{array}{c}22,55 \\
* * *\end{array}$ & $\begin{array}{c}53,56 \\
* * *\end{array}$ & $\begin{array}{c}109,09 \\
* * *\end{array}$ & $\begin{array}{c}28,37 \\
* * *\end{array}$ & $\begin{array}{c}127,45 \\
* * *\end{array}$ & $\begin{array}{l}7,8 \\
* *\end{array}$ & $\begin{array}{c}183,13 \\
* * *\end{array}$ & $\begin{array}{c}242,75 \\
* * *\end{array}$ & $\begin{array}{c}87,01 \\
* * *\end{array}$ \\
\hline$p$-érték & 0,000 & 0,000 & 0,000 & 0,000 & 0,000 & 0,000 & 0,000 & 0,050 & 0,000 & 0,000 & 0,000 \\
\hline \multicolumn{12}{|c|}{ Sharpe-ráták } \\
\hline$\chi^{2}$ & 1,767 & 3,161 & 1,285 & 1,127 & 3,416 & 0,828 & 0,075 & 0,635 & 2,226 & 2,447 & 0,884 \\
\hline p-érték & 0,622 & 0,367 & 0,733 & 0,771 & 0,332 & 0,843 & 0,995 & 0,888 & 0,527 & 0,485 & 0,829 \\
\hline
\end{tabular}

A loghozamokat vizsgálva mind a Russell 3000 Indexnél, mind a faktorok többségénél minden racionális szignifikanciaszinten elvethető a $\mathrm{H}_{0}$ hipotézis, azaz megfigyelhető az ARCH-hatás. Az osztalékfaktor 1 százalékon nem szignifikáns, 5 százalékon azonban még éppen igen. A Sharpe-rátákat elemezve megállapítható, hogy egyik faktor vonatkozásában sem figyelhető meg az ARCH-hatás, azaz a $\mathrm{H}_{0}$ hipotézist nem tudjuk elvetni. Amennyiben a Sharpe-rátákat a 2. ábrának megfelelő módon ábrázolnánk, láthatnánk, hogy nincs érdemi volatilitás-klasztereződés. Az eredményeink alapján egyszerű OLS-regresszióval fogjuk a Sharpe-ráták teljesítményét tesztelni. Minthogy autokorreláció nem figyelhető meg, a következő eldöntendő kérdés a hibatagok heteroszkedasztikusságát vizsgálja. A kapcsolódó Breusch-Pagan (BP)-próba megtalálható a 4. táblázatban.

${ }^{20}$ Korábban már említettük, hogy a GARCH-modellek alkalmazásakor sokszor nem is a klasszikus regressziós következtetések levonása a cél, hanem a feltételes varianciák (volatilitások) modellezése. 


\section{2. ábra}

A Russell 3000 index és a tiszta faktorportfóliók heti loghozamai 2000 és 2018 között
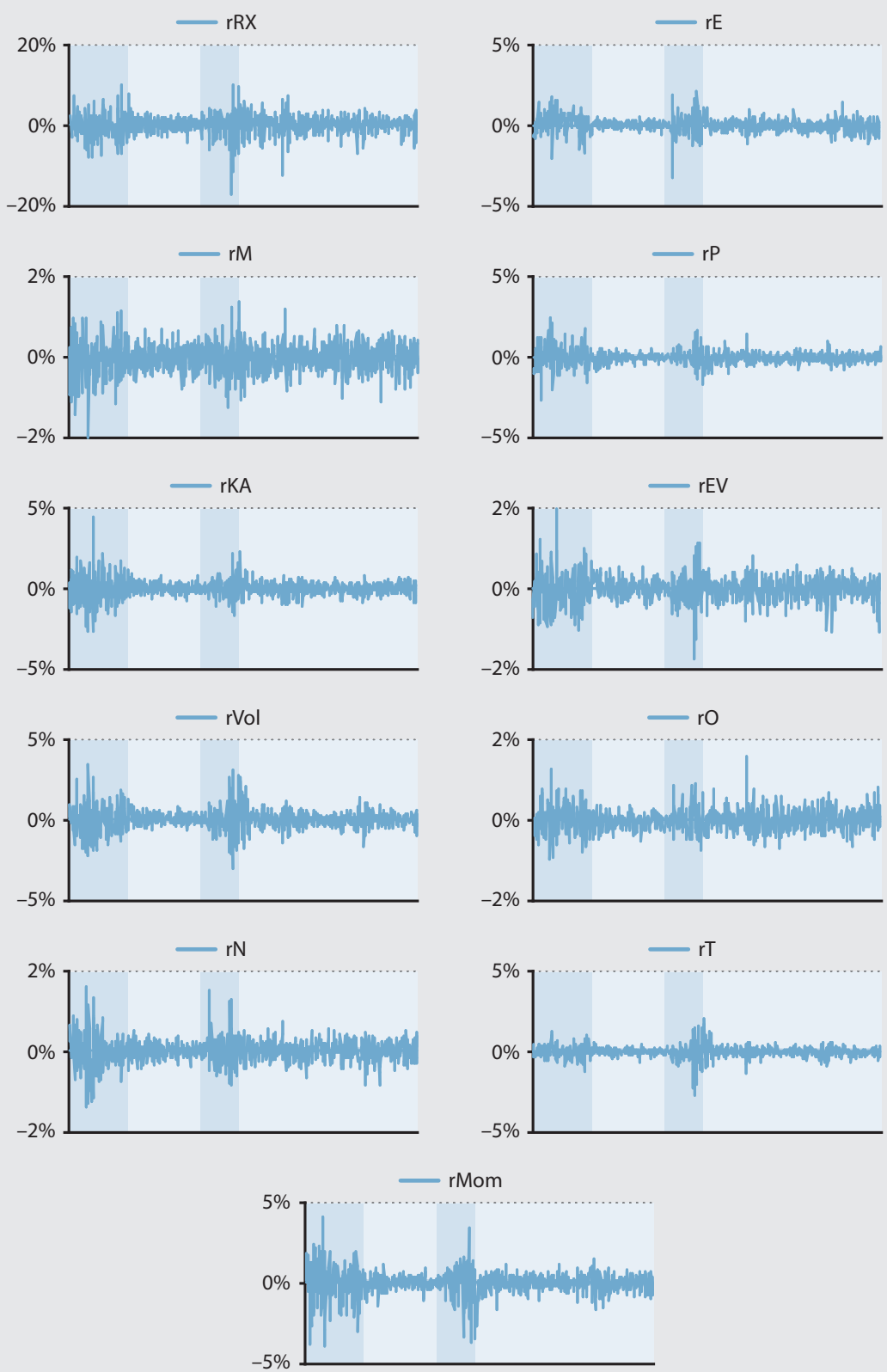

Megjegyzés: Lásd 2. táblázat. 


\begin{tabular}{|c|c|c|c|c|c|c|c|c|c|c|}
\hline \multicolumn{11}{|c|}{ 4. táblázat } \\
\hline BP & E & M & $\mathbf{P}$ & KA & EV & Vol & 0 & $\mathbf{N}$ & $\mathbf{T}$ & Mom \\
\hline \multicolumn{11}{|c|}{ Konstans variancia } \\
\hline \multicolumn{11}{|c|}{ Heteroszkedaszticitás } \\
\hline$\chi^{2}$ & $\begin{array}{l}9,58 \\
* * *\end{array}$ & 0,43 & 0,09 & $\begin{array}{c}12,67 \\
* * *\end{array}$ & $\begin{array}{c}3,15 \\
*\end{array}$ & $\begin{array}{c}5,75 \\
* *\end{array}$ & $\begin{array}{c}37,60 \\
* * *\end{array}$ & $\begin{array}{c}12,32 \\
* * *\end{array}$ & $\begin{array}{c}18,22 \\
* * *\end{array}$ & 2,36 \\
\hline p-érték & 0,002 & 0,512 & 0,766 & 0,000 & 0,076 & 0,017 & 0,000 & 0,000 & 0,000 & 0,125 \\
\hline
\end{tabular}

Megjegyzés: Lásd 2. táblázat. *** 1 százalékon szignifikáns, ** 5 százalékon szignifikáns, * 10 százalékon szignifikáns

A szokásosnak tekinthető 5 százalékos szignifikanciaszint mellett a méret, a profitabilitás, az eredmény változékonysága és a momentumfaktorok esetében nem tudjuk elvetni a $\mathrm{H}_{0}$ hipotézist, azaz e faktorok hibatagjairól feltesszük, hogy homoszkedasztikusak. A többi faktor maradékváltozói a BP-teszt alapján heteroszkedasztikusak, így ezeknél az OLS-regresszió robosztus változatát fogjuk alkalmazni.

\section{Empirikus eredmények}

Tanulmányunk jelen fejezetében ismertetjük empirikus vizsgálódásunk eredményeit. A hipotéziseink a következők:

1. hipotézis: Adott tiszta faktorportfólió többlethozamot eredményezett a passzív stratégiához képest.

Formálisan felírva:

$$
\begin{aligned}
& H_{0}: R P(\text { faktor })=M R P \text {, másképpen } \beta_{0}=0^{21} \\
& H_{A}: R P(\text { faktor }) \neq M R P \text {, másképpen } \beta_{0} \neq 0
\end{aligned}
$$

2. hipotézis: Adott tiszta faktorportfólió kockázattal korrigált többlethozamot eredményezett a passzív stratégiához képest.

Formálisan felírva:

$$
\begin{aligned}
& \mathrm{H}_{0} \text { : Sharpe }(\text { faktor })=\text { Sharpe }(\text { passzív stratégia) } \\
& \mathrm{H}_{\mathrm{A}} \text { : Sharpe }(\text { faktor }) \neq \text { Sharpe (passzív stratégia) }
\end{aligned}
$$

\footnotetext{
${ }^{21}$ Az RP és az MRP a kockázatmentes hozamon felüli kockázati prémium és piaci kockázati prémium rövidítése. A kockázatmentes hozam az adott időpontra vonatkozó 1 hónapos amerikai T-Bill hozama. A Jensen-féle alfa a regressziós módszertanban megegyezik a tengelymetszettel, amelyet legtöbbször $\beta_{0}$-lal szokás jelölni. A befektetések irodalmában az alfa voltaképpen egy „kitüntetett” $\beta_{0}$.
} 
A fenti hipotézisek voltaképpen a szakirodalmi fejezetben bemutatott piaci anomáliák próbái, de egyúttal a hatékony piacok tesztjeként is értelmezhetőek. A hipotéziseinket megvizsgáljuk a teljes elemzett időszakra (2000-2018), a válságos évekre (2000-2009) és a válságot követő fellendülési periódusra is (2009-2018). A teljes időszak szakaszokra osztásával fő hipotéziseink voltaképpen alhipotézisekkel bővülnek: lehetséges-e az egyes faktorportfóliókkal a válság (fellendülés) éveiben a piachoz képest kockázattal korrigált többlethozamra szert tenni.

Az első hipotézis a Jensen-féle alfát értékeli, és teszteléséhez a feltételes varianciákon és kovarianciákon alapuló regressziós modellt, a DCC GARCH-modellt alkalmazzuk. A második hipotézis a Sharpe-ráta tesztje. A Sharpe-ra vonatkozó hipotézisek igazolásához - amely faktoroknál szükséges - a heteroszkedaszticitást kezelő OLS-alapú regressziós modellt fogjuk felhasználni (egyébként a klasszikus OLS a számítások alapja).

A regressziós számítások eredményeinek részletes elemzése előtt célszerű megvizsgálni az egyes faktorok és a piaci portfólió elmúlt 19 évének a teljesítményét. A 3. ábra a Russell 3000 Index és a 10 faktorportfólió kumulált loghozamát ábrázolja heti adatok alapján. Megkülönböztetjük a válságos éveket a fellendülés időszakától, továbbá ábrázoljuk a teljes 19 éves kumulált hozamsort is.

A teljes időszakot vizsgálva látható, hogy a piaci index ( $R X)$ teljesítménye (a fekete folytonos vonal) 2018 végére lényegében utolérte az értékfaktort ( $E$ vonal). A válság alatt az értékfaktor jobban teljesített az összes többi stratégiánál, valamint a piac egészénél is. Ebben az időszakban az egyes tiszta faktorok kumulált hozama többször meghaladta a piaci portfólió hozamát. Az elmúlt tíz évben változás következett be, és a piaci hozam lényegesen magasabb volt a faktorhozamoknál. 


\section{3. ábra}

A Russell 3000 Index és a tiszta faktorportfóliók kumulált loghozamai 2000 és 2018 között
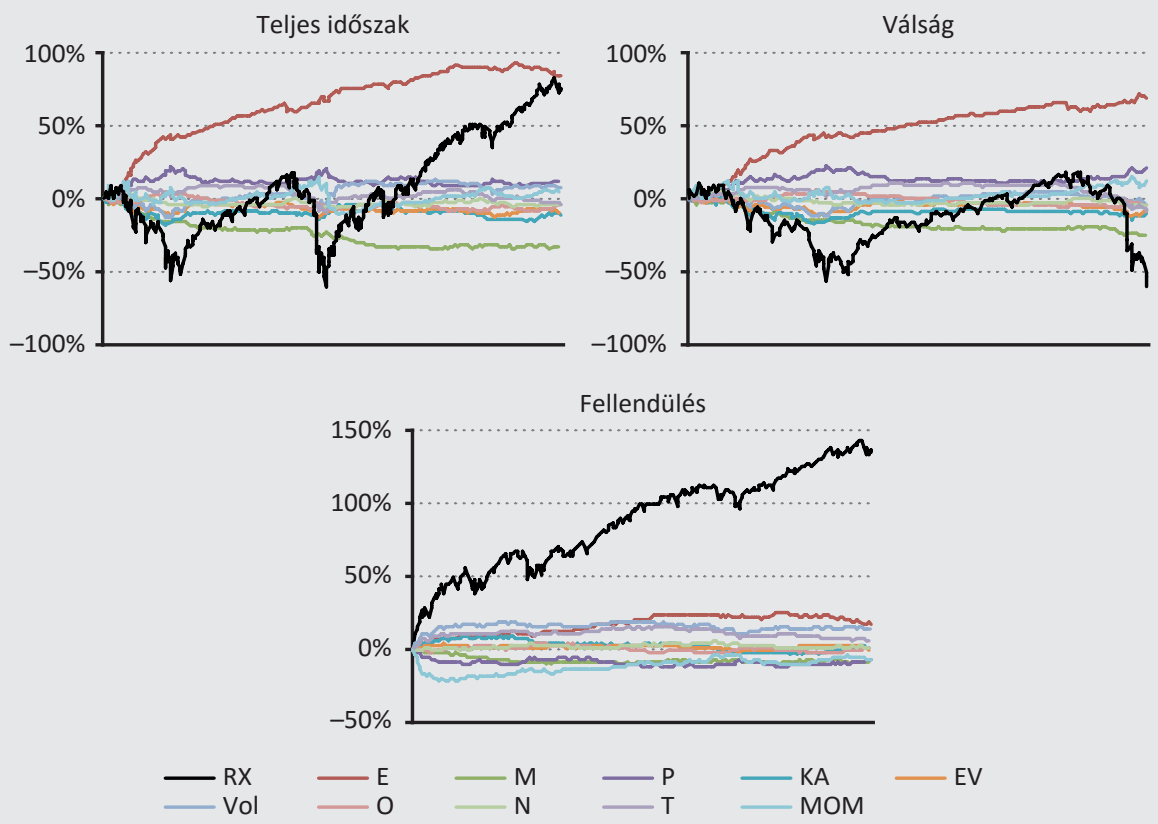

Megjegyzés: Lásd 2. táblázat.

A 3. ábra alapján az a benyomásunk keletkezhet, hogy a faktorportfóliók kevésbé volatilisek, mint a piaci portfólió. Ez a fejlemény éppen a tiszta faktorportfóliók konstrukciójukból következik: kiszűrik az egyéb faktorok hatását, ezáltal megragadhatóbbá válik a tényleges hozam-szórás kapcsolat, így csökken a szórás is (lásd Menchero - Lee 2015:83 és Clarke et al. 2017:27). A piac teljes kockázatossága és a különféle faktorok volatilitása közötti kapcsolat vizsgálatával összefüggésben érdemes kiemelni Csóka et al. (2009) tanulmányát. A szerzők cikkükben belátják, hogy mindig felosztható a kockázat stabil módon úgy, hogy az alegységek (faktorok) egyetlen részhalmaza (koalíciója) sem ellenkezik az adott felosztás ellen.

Az 5. táblázat a faktorok és a piac elmúlt éveinek átlagos hozamát, szórását, valamint a teljesítménymutatókat tartalmazza. Az átlagos hozamra és a szórásra vonatkozó számadatok heti loghozamokból számított éves értékek ${ }^{22}$.

${ }^{22}$ A számítások módszertani háttere a következő (a képletek részletesebb összefüggéseit lásd Medvegyev - Száz 2010:15-17): a heti loghozamok - $\ln \left(S_{t} / S_{t-1}\right)$ - számtani átlagolását követően elóáll az átlagos heti

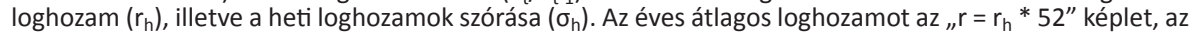
éves átlagos szórást pedig a „ $\sigma=\sigma_{\mathrm{h}} * \sqrt{ } 52$ ” összefüggés alapján számítjuk. Az átlagos éves Sharpe-rátát az évesített hozamok és évesített szórás felhasználásával, a (15) képletbe történő behelyettesítéssel kapjuk. Az éves átlagos Jensen-alfa a GARCH-regresszió outputja (a regresszió átlagos heti alfát számol, amelyet 52-vel megszorozva jutunk el az átlagos éves alfához). 


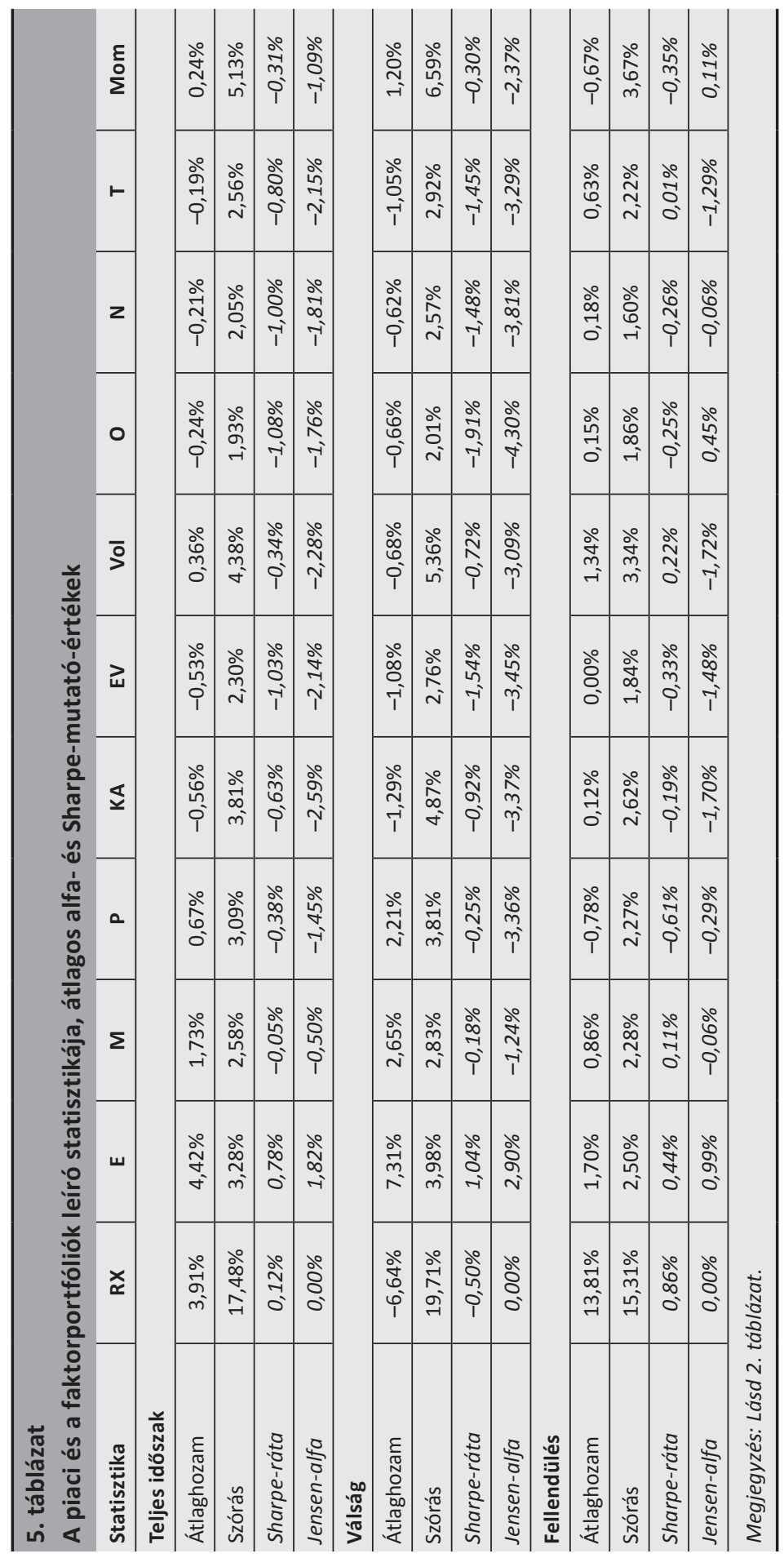


A teljes időszakot (2000-2018) vizsgálva megállapítható, hogy a legmagasabb hozama az értékfaktornak (4,42 százalék) volt. Pozitiv hozamot lehetett még elérni a passzív stratégiával (3,91 százalék), a kisvállalati faktorral (1,73 százalék), a profit faktorral ( 0,67 százalék), valamint a volatilitás ( 0,36 százalék) és momentumfaktorral (0,24 százalék). Amennyiben korrigálunk a kockázattal (Sharpe-mutató), akkor a legjobb teljesítmény továbbra is az értékfaktorhoz tartozik ( 0,78 százalék, szemben a piac 0,12 százalékával), miközben a jövedelmezőségi (profit), a kisvállalati, a volatilitás- és a momentumfaktor eredményessége már negativ. A további faktorok átlagos éves hozama enyhén negatív volt.

A „válság” időszakában (2000 és 2009 között) pozitív hozamra lehetett szert tenni az érték- ( 7,31 százalék), a méret- (2,65 százalék), a profit- (2,21 százalék) és a momentumfaktorral (1,20 százalék). A passzív stratégia meglehetősen rosszul teljesített (-6,64 százalék). Megfigyelhető, hogy a többi faktor hozama ugyan negativ értéket vett fel, a veszteség azonban minden esetben alacsonyabb volt a piaci faktoréhoz képest. Általánosságban elmondható, hogy a válság éveiben magasabb volt a volatilitás, mint a teljes vizsgált időszakban, így a Sharpe-ráták az értékfaktort leszámítva negatívak.

A „,növekedés” éveiben (2009 és 2018 között) - a profit-, a momentum- és az eredmény változékonysága faktort leszámítva - pozitiv hozamokat figyelhetünk meg, csökkenő volatilitás mellett. Mindenesetre a pozitív hozamok leginkább nullához közeli értékek. Ekkor a piaci portfólió bőségesen felülteljesítette a faktorportfóliókat: hozama 13,81 százalék volt, szemben a faktorok átlagosan évi 0,35 százalékos teljesítményével.

A 6. táblázat tartalmazza a többlethozamra vonatkozó hipotézisvizsgálataink eredményeit. Megállapítható, hogy a kétféle teljesítménymutató alapján lényegében ugyanazokra a következtetésekre juthatunk, ezért a következőkben csupán a Jensen-féle alfát elemezzük. 


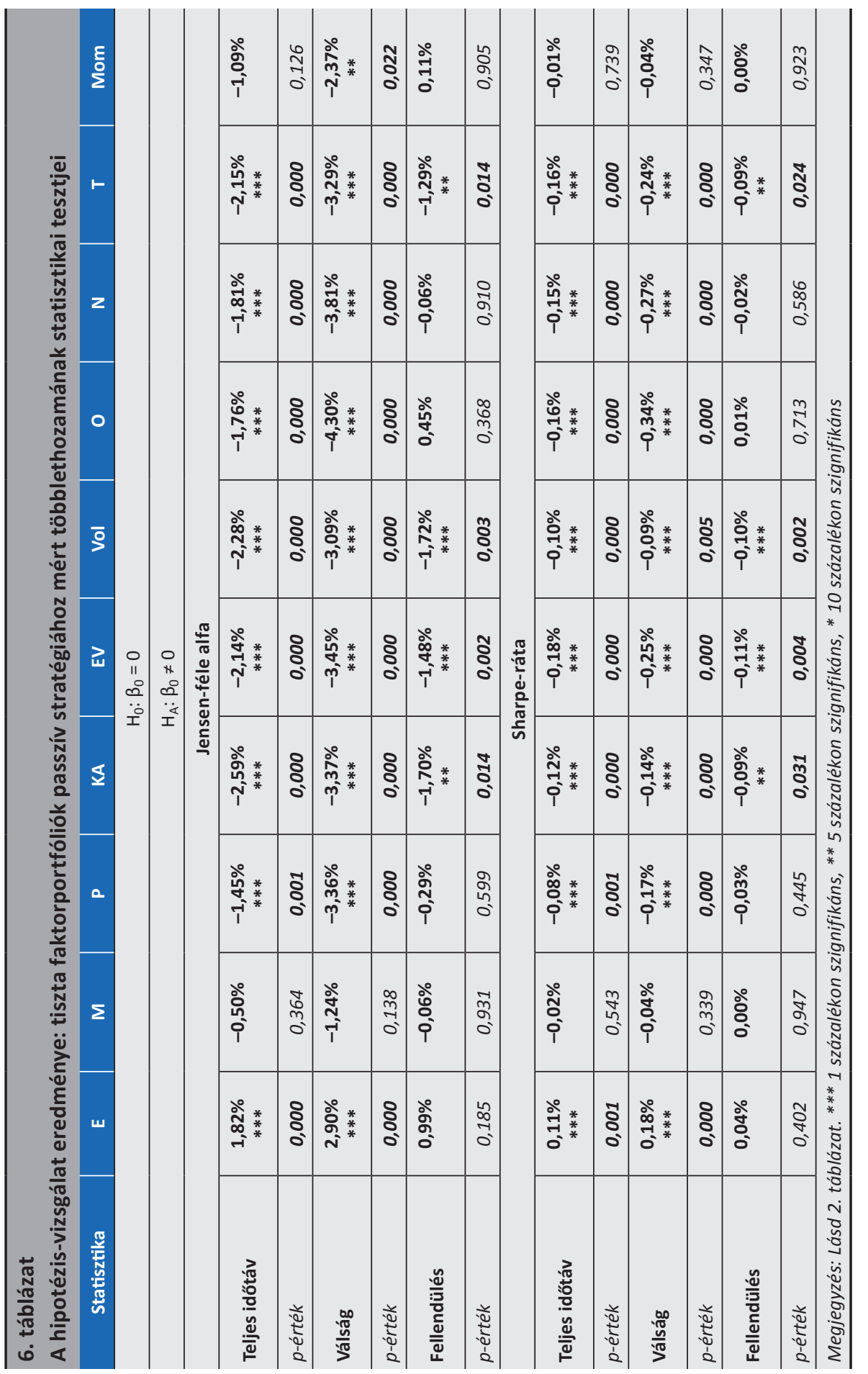


Érdekes fejlemény, hogy sem a méret-, sem a momentumfaktorokkal nem lehetett szignifikáns többlethozamot elérni, függetlenül a vizsgált időszaktól ${ }^{23}$, azaz a zéró többlethozamra vonatkozó nullhipotézist a racionálisnak tekinthető szignifikanciaszinteken nem tudjuk elvetni. Ez részben egybecseng Clarket et al. (2017) és Beard - Sias (1997) következtetéseivel, és valószínúleg annak tudható be, hogy a '90-es évektől egyre elterjedtebb lett a befektetők körében e stratégiák alkalmazása.

Érdemi különbség figyelhető meg a faktorok szignifikanciájában a válságos éveket és a fellendülés időszakát külön-külön vizsgálva. A válság éveiben a méretfaktort leszámítva az összes faktorral szignifikáns többlethozamot lehetett elérni (a p-értékek lényegében nullák). Ezzel szemben a fellendülés időszakában a faktorok többségével már nem lehetett szignifikáns többlethozamot realizálni, vagyis nem tudjuk elvetni a nullhipotézist. Nem lehetett tehát többlethozamot elérni az érték-, a méret-, a profitabilitás-, az osztalék-, a növekedés- és a momentumfaktorral, ugyanakkor kivételt jelentettek a kockázatosságot mérő faktorok (eredmény változékonysága, volatilitás és tőkeáttétel), valamint az eszközök likviditását megragadó kereskedési aktivitás faktor.

Az alábbiakban megvizsgáljuk a szignifikánsnak minősített faktorok többlethozamának az irányát, azaz választ keresünk arra a kérdésre, hogy milyen befektetési stratégia volt üdvözítő az elmúlt közel 20 évben. Értékelésünket egyszerre két dimenzió mentén fogjuk ismertetni: egyrészt a szakirodalom és a befektetési gyakorlat alapján kialakult vételi vagy eladási ajánlás, másrészt az empirikus eredményeink alapján ex-post vételi vagy eladási stratégia alapján. A két dimenzió összesen négy lehetséges kimenetet eredményezhet:

1) Konszenzusos vétel: mind az előfeltevés, mind az empirikus eredmény szerint a vételi pozíció eredményezett többlethozamot.

2) Kontra-vétel: az előfeltevés eladást prognosztizál, ezzel szemben az empirikus eredmény szerint a vételi pozíció eredményezett többlethozamot.

3) Konszenzusos eladás: mind az előfeltevés, mind az empirikus eredmény szerint eladási pozíció eredményezett többlethozamot.

4) Kontra-eladás: az előfeltevés vételt prognosztizál, ezzel szemben az empirikus eredmény szerint az eladási pozíció eredményezett többlethozamot.

\footnotetext{
${ }^{23}$ A momentumfaktor 5 százalékon szignifikáns a válságos években (1 százalékon nem), és negatív a hozama. Ez az eredmény - tekintve, hogy az elmúlt egy év kumulált hozama a faktorképző változó - ellentmond Jegadeesh és Titman 1993-as és 2001-es eredményeinek, célszerű volt kontrastratégiát követni (lásd a 4. ábrát).
} 
A „konszenzusos” kifejezés utal arra, hogy a szakirodalmi ajánlások és empirikus eredményeink megfelelnek egymásnak, míg a „kontra” jelöléssel a szakirodalmi várakozásokkal ellentétes empirikus eredményeinket jelöljük. Előbbieknél ajánlott volt a szakirodalmi ajánlásoknak megfelelően kereskedni, míg utóbbi esetekben célszerúnek látszott szembemenni a korábbi tapasztalatok alapján megfogalmazott stratégiákkal (ez az ún. kontrastratégia, angolul contrarian strategy).
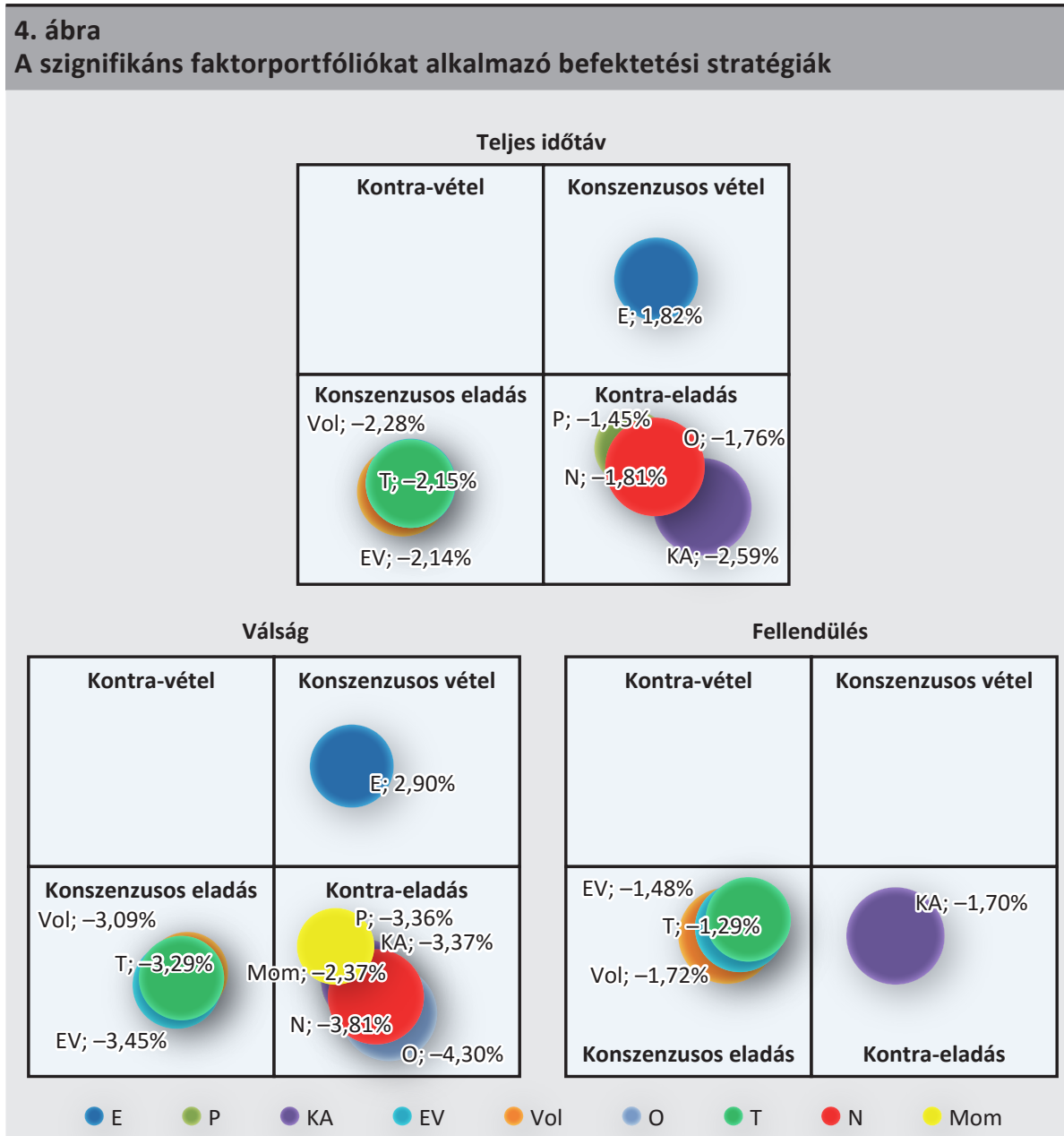

Megjegyzés: Az ábrán szereplö buborékok mérete a többlethozam nagyságát ragadja meg. A színkódok az egyes aktív stratégiák időszakokon átnyúló következetes jelölésére szolgálnak. Lásd 2. táblázat. 
A 4. ábra első síknegyedében, a konszenzusos vétel kategóriájában csupán az értékfaktor szerepel, azaz a szakirodalom alapján ennél a faktornál pozitív többlethozamot vártunk, amit az empirikus eredményeink végül megerősítettek. A teljes időszakban és a válságos években az alfa értéke rendre 1,82 és 2,90 százalék volt. A fellendülés időszakában nem volt olyan faktor, amely szignifikánsan felülteljesítette volna a passziv stratégiát.

Kontra-vételre nem kaptunk szignifikáns ajánlást, azaz az elmúlt 20 évben nem volt olyan faktor, amely a szakirodalom negatív többlethozamra vonatkozó várakozásával szemben pozitív alfát eredményezett volna. Ez a megállapítás igaz a válság és a fellendülés éveire is.

A kockázatosságot mérő faktoroknál, vagyis az eredmény változékonyságánál, a volatilitásnál és a tőkeáttételnél az empirikus kutatásunk megerősíti a piaci anomáliák szakirodalma alapján várt negatív hozamtöbbletet. A konszenzusos short stratégia érvényesült mindhárom faktornál nemcsak a teljes, de a két részidőszakban is. A többlethozam a teljes időszakban rendre $-2,14,-2,28$ és $-2,15$ százalék volt.

Meglepő eredményeket kaptunk a kereskedési aktivitás, az osztalék, a növekedés és a profitabilitás faktorokra. A hipotézisünk pozitiv többlethozamra vonatkozott, ezzel szemben szignifikáns negatív hozamokkal szembesültünk. Célszerű volt kontra eladási stratégiát (short) alkalmazni. Mindenesetre a fellendülés éveiben csak a kereskedési aktivitás volt szignifikáns. A teljes időszaki többlethozam rendre $-2,59$, $-1,76,-1,81$ és $-1,45$ százalék volt.

\section{8. Összegzés}

Tanulmányunkban többváltozós keresztmetszeti regressziók alapján összeállított tiszta faktorportfóliókat (pure factor portfolios) alkalmaztunk hipotéziseink teszteléshez, amelyek szerint aktív befektetési stratégiák alkalmazásával többlethozamot lehet realizálni a passzív stratégiához képest. Hipotéziseink a piaci hatékonyság próbájaként is értelmezhetók. A faktorok teljesítményét a Jensen-féle alfával és a Sharpe-rátával mértük.

Elemzési univerzumunk az Egyesült Államok részvénypiaca volt a 2000 és 2018 között időszakban, a benchmark portfóliót a Russell 3000 Index képviselte. Ebben az időszakban két jelentős válság is lezajlott, ezért kettébontva vizsgáltuk az idősort: a 2000 és 2009 közötti időszakot a „válság”, a 2009-et követő időszakot a "fellendülés" éveinek neveztük el. A vizsgált faktorok a következők voltak: érték, méret, profit, kereskedési aktivitás, eredmény változékonyság, volatilitás, osztalék, növekedés, tőkeáttétel és momentum. 
Empirikus kutatásunk legfontosabb eredményei a következők: a szakirodalomban sokszor hivatkozott méret- és momentumfaktor többlethozama nem volt szignifikáns sem a teljes időszakban, sem a fellendülés éveiben. A válságos években a méretfaktor továbbra sem szignifikáns, a momentum azonban már igen. Jellemző volt továbbá, hogy a fellendülés éveiben a legtöbb faktor többlethozama nem különbözik szignifikánsan nullától (kivételek a kockázatosságot és a kereskedési aktivitást mérő portfóliók). E faktorok és időszakok vonatkozásában nem tudtuk igazolni a többlethozamra vonatkozó hipotéziseinket.

A vizsgált időszakokban szignifikáns többlethozamot eredményező faktorok befektetési stratégiáit mutattuk be végül. A befektetési stratégiát úgy határoztuk meg, hogy összevetettük a szakirodalom és a befektetési gyakorlat alapján kialakult vételi vagy eladási ajánlást az ex-post eredményekkel. Az elmúlt közel 20 évben a várakozásoknak megfelelően szignifikáns pozitív többlethozamot (alfa 1,82 százalék) csupán a tiszta értékfaktorral lehetett elérni, azaz itt konszenzusos vételi stratégiát volt érdemes követni. Kutatásunk e részeredménye összhangban van Fama és French munkásságával. A kockázatosságot megragadó faktorok (eredmény változékonysága, volatilitás, tőkeáttétel) többlethozama szignifikáns és negatív $(-2,14,-2,28$ és $-2,15$ százalék), ami szintén megfelel a szakirodalomban szereplő várakozásoknak, azaz a konszenzusos eladási befektetési stratégia volt sikeres. Az elvárttal ellentétes, negatív eredményeket kaptunk a jövedelmezőségi, a növekedési, az osztalék- és kereskedési aktivitást mérő faktornál, ezért itt a befektetők kontra eladási stratégiával érhettek el többlethozamot. Eredményeink összességében erősítik a szakirodalomban is említett piaci hatékonyság gyenge formáját.

\section{Felhasznált irodalom}

Ang, A. - Hodrick, R.J. - Xing, Y. - Zhang, X. (2006): The Cross-Section of Volatility and Expected Returns. The Journal of Finance, 61(1): 259-299. https://doi.org/10.1111/j.15406261.2006.00836.x

Ang, A. - Hodrick, R.J. - Xing, Y. - Zhang, X. (2009): High idiosyncratic volatility and low returns: International and further U.S. evidence. Journal of Financial Economics, 91(1): 1-23. https://doi.org/10.1016/j.jfineco.2007.12.005

Arbel, A. - Carvell, S. - Strebel, P. (1983): Giraffes, Institutions and Neglected Funds. Financial Analysts Journal, 39(3): 57-63. https://doi.org/10.2469/faj.v39.n3.57

Baker, M. - Bradley, B. - Wurgler, J. (2011): Benchmarks as Limits to Arbitrage: Understanding the Low-Volatility Anomaly. Financial Analysts Journal, 67(1): 40-54. https://doi. org/10.2469/faj.v67.n1.4 
Bali, T.G. - Cakici, N. - Whitelaw, R.F. (2011): Maxing out: Stocks as lotteries and the crosssection of expected returns. Journal of Financial Economics, 99(2): 427-446. https://doi. org/10.1016/j.jfineco.2010.08.014

Banz, R.W. (1981): The Relationship Between Return and Market Value of Common Stock. Journal of Financial Economics, 9(1): 3-18. https://doi.org/10.1016/0304-405X(81)90018-0

Basu, S. (1977): Investment Performance of Common Stocks in Relation to Their PriceEarnings Ratios: A Test of the Efficient Market Hypothesis. The Journal of Finance, 32(3): 663-682. https://doi.org/10.1111/j.1540-6261.1977.tb01979.x

Basu, S. (1983): The Relationship Between Earnings' Yield, Market Value and Return for NYSE Common Stocks. Journal of Financial Economics, 12(1): 129-156. https://doi. org/10.1016/0304-405X(83)90031-4

Beard, C.G. - Sias, R.W. (1997): Is There a Neglected-Firm Effect? Financial Analysts Journal, 53(5): 19-23. https://doi.org/10.2469/faj.v53.n5.2113

Berlinger Edina - Walter György (1999): Faktormodellek az értékpapírpiacon. Bankszemle, 43(4): 34-43.

Blitz, D.C. - van Vliet, P. (2007): The Volatility Effect. The Journal of Portfolio Management, 34(1): 102-113. https://doi.org/10.3905/jpm.2007.698039

Bodie, Z. - Kane, A. - Marcus, A.J. (2011): Investments. McGraw-Hill/Irwin, p. 331.

Bollerslev, T. (1986): Generalized Autoregressive Conditional Heteroscedasticity. Journal of Econometrics, 31(3): 307-327. https://doi.org/10.1016/0304-4076(86)90063-1

Brown, C.K. - Harlow, W.V. (1988): Market overreaction: Magnitude and Intensity. The Journal of Portfolio Management, 14(2): 6-13. https://doi.org/10.3905/jpm.1988.409137

Cahan, E. - Ji, L. (2016): US Equity Fundamental Factor Model. Bloomberg whitepapers, pp. 1-33.

Capaul, C. - Rowley, I. - Sharpe, W.F. (1993): International Value and Growth Stock Returns. Financial Analysts Journal, 49(1): 27-36. https://doi.org/10.2469/faj.v49.n1.27

Carhart, M.M. (1997): On Persistence in Mutual Fund Performance. The Journal of Finance, 52(1): 57-82. https://doi.org/10.1111/j.1540-6261.1997.tb03808.x

Carvell, S.A. - Strebel, P.J. (1987): Is There A Neglected Firm Effect? Journal of Business Finance and Accounting, 14(2): 279-290. https://doi.org/10.1111/j.1468-5957.1987. tb00544.x 
Chan, L.K.C. - Hamao, Y. - Lakonishok, J. (1991): Fundamentals and Stock Returns in Japan. The Journal of Finance, 46(5): 1739-1764. https://doi.org/10.1111/j.1540-6261.1991. tb04642.x

Chen, N-F. - Roll, R. - Ross, S. A. (1986): Economic Forces and the Stock Market. The Journal of Business, 59(3): 383-403. https://doi.org/10.1086/296344

Chien-Ting, L. (1999): Misspecification of capital asset pricing model (CAPM): Implication for size and book-to-market effects. PhD thesis, Texas Tech University. https://ttu-ir.tdl.org/ handle/2346/16603?show=full. Letöltés ideje: 2018. November 25.

Clarke, R. - De Silva, H. - Thorley S. (2017): Pure Factor Portfolios and Multivariate Regression Analysis. The Journal of Portfolio Management, 43(3): 16-31. https://doi.org/10.3905/ jpm.2017.43.3.016

Cochrane, J.C. (2011): Presidential Address: Discount Rates. The Journal of Finance, 66(4): 1047-1108. https://doi.org/10.1111/j.1540-6261.2011.01671.x

Conrad, J. - Kaul, G. (1988): Time-Variation in Expected Returns. The Journal of Business, 61(4): 409-425. https://doi.org/10.1086/296441

Csóka, P. - Herings, P.J.J. - Kóczy, L.Á. (2009): Stable allocations of risk. Games and Economic Behavior, 67(1): 266-276. https://doi.org/10.1016/j.geb.2008.11.001

Damodaran, A. (2012): Investment Valuation. Tools and Techniques for Determining the Value of Any Asset. John Wiley \& Sons, p. 116.

De Bondt, W.F.M. - Thaler, R. (1985): Does the Stock Market Overreact? The Journal of Finance, 40(3): 793-805. https://doi.org/10.1111/j.1540-6261.1985.tb05004.x

De Bondt, W.F.M. - Thaler, R. (1987): Further Evidence on Investor Overreaction and Stock Market Seasonality. The Journal of Finance, 42(3): 557-581. https://doi. org/10.1111/j.1540-6261.1987.tb04569.x

De Bondt, W.F.M. - Thaler, R. (1989): Anomalies: A Mean-Reverting Walk Down Wall Street. The Journal of Economic Perspectives, 3(1): 189-202. https://doi.org/10.1257/jep.3.1.189

Eling, M. - Schuhmacher, F. (2007): Does the choice of performance measure influence the evaluation of hedge funds? Journal of Banking \& Finance, 31(9): 2632-2647. https://doi. org/10.1016/j.jbankfin.2006.09.015

Engle, R.F. (1982): Autoregressive Conditional Heteroscedasticity with Estimates of the Variance of United Kingdom Inflation. Econometrica, 50(4): 987-1008. https://doi. org/10.2307/1912773 
Engle, R.F. (2002): Dynamic conditional correlation: A simple class of multivariate generalized autoregressive conditional heteroscedasticity models. Journal of Business \& Economic Statistics, 20(3): 339-350. https://doi.org/10.1198/073500102288618487

Fama, E.F. (1970): Efficient Capital Markets: A Review of Theory and Empirical Work. The Journal of Finance, 25(May): 383-417. https://doi.org/10.2307/2325486

Fama, E.F. - Blume, M.E. (1966): Filter Rules and Stock-Market Trading. The Journal of Business, 39(1/Part 2): 226-241. https://doi.org/10.1086/294849

Fama, E.F. - French, K.R. (1992): The Cross-Section of Expected Stock Returns. The Journal of Finance, 47(2): 427-465. https://doi.org/10.1111/j.1540-6261.1992.tb04398.x

Fama, E.F. - French, K.R. (1996): Multifactor Explanations of Asset Pricing Anomalies. The Journal of Finance, 51(1): 55-84. https://doi.org/10.1111/j.1540-6261.1996.tb05202.x

Fama, E.F. - French, K.R. (2015): A five-factor asset pricing model. Journal of Financial Economics, 116(1): 1-22. https://doi.org/10.1016/j.jfineco.2014.10.010

Fama, E.F. - MacBeth, J.D. (1973): Risk, Return, and Equilibrium: Empirical Tests. The Journal of Political Economy, 81(3): 607-636. https://doi.org/10.1086/260061

Farinelli, S. - Ferreira, M. - Rossello, D. - Thoeny, M. - Tibiletti, L. (2008): Beyond Sharpe ratio: Optimal asset allocation using different performance ratios. Journal of Banking \& Finance, 32(10): 2057-2063. https://doi.org/10.1016/j.jbankfin.2007.12.026

Fernandez, P. (2015): CAPM: An Absurd Model. Business Valuation Review, 34(1): 4-23. https://doi.org/10.5791/0882-2875-34.1.4

Fernandez, P. - Acín, I.F. (2015): Expected and Required returns: very different concepts. SSRN: https://ssrn.com/abstract=2591319. Letöltés ideje: 2018. június 15.

Frazzini, A. - Pedersen, L.H. (2014): Betting against beta. Journal of Financial Economics, 111(1): 1-25. https://doi.org/10.1016/j.jfineco.2013.10.005

Howe, J.S. (1986): Evidence on Stock Market Overreaction. Financial Analysts Journal, 42(4): 74-77. https://doi.org/10.2469/faj.v42.n4.74

Jegadeesh, N. - Titman, S. (1993): Returns to Buying Winners and Selling Losers: Implications for Stock Market Efficiency. The Journal of Finance, 48(1): 65-91. https:// doi.org/10.1111/j.1540-6261.1993.tb04702.x

Jegadeesh, N. - Titman, S. (2001): Profitability of Momentum Strategies: An Evaluation of Alternative Explanations. The Journal of Finance, 56(2): 699-720. https://doi. org/10.1111/0022-1082.00342 
Jensen, M.C. (1968): The Performance Of Mutual Funds In The Period 1945-1964. Journal of Finance, 23(2): 389-416. https://doi.org/10.1111/j.1540-6261.1968.tb00815.x

Kahneman, D. - Tversky, A. (1979): Prospect Theory: An Analysis of Decision Under Risk. Econometrica, 47(2): 263-291. https://doi.org/10.2307/1914185

Kasper, L.J. (1997): Business Valuations: Advanced Topics. Greenwood Publishing Group, p. 20.

Lintner, J. (1965): The Valuation of Risk Assets and the Selection of Risky Investments in Stock Portfolios and Capital Budgets. The Review of Economics and Statistics, 47(1): 13-37. https://doi.org/10.2307/1924119

Lo, A.W. - MacKinlay, A.C. (1988): Stock Market Prices do not Follow Random Walks: Evidence from a Simple Specification Test. The Review of Financial Studies, 1(1): 41-66. https:// doi.org/10.1093/rfs/1.1.41

Lovas Anita (2017): Eszközárazás és portfóliókezelés. Budapesti Corvinus Egyetem, Budapest.

Malkiel, B.G. (2001): Bolyongás a Wall Streeten. Nemzetközi Bankárképző Rt.

Markowitz, H. (1952): Portfolio Selection. The Journal of Finance, 7(1): 77-91. https://doi. org/10.2307/2975974

Medvegyev Péter - Száz János (2010): A meglepetések jellege a pénzügyi piacokon Kockázatok vételre és eladásra. Bankárképző, Budapest.

Menchero, J. (2010): The Characteristics of Factor Portfolios. The Journal of Performance Measurement, 15(1): 52-62.

Menchero, J. - Ji, L. (2017): Pure Factor Returns in Real Time. Bloomberg White Papers, pp. $1-14$.

Menchero, J. - Lee, J-H. (2015): Efficiently Combining Multiple Sources of Alpha. Journal of Investment Management, 13(4): 71-86.

Mossin, J. (1966): Equilibrium in a Capital Asset Market. Econometrica, 34(4): 768-783. https://doi.org/10.2307/1910098

Naffa Helena (2009): Eszközárazási anomáliák többváltozós modellje. Hitelintézeti Szemle, 8(6): 516-527. http://epa.oszk.hu/02700/02722/00044/pdf/EPA02722_hitelintezeti_ szemle_2009_6_516-527.pdf

Novy-Marx, R. (2013): The Other Side of Value: The Gross Profitability Premium. Journal of Financial Economics, 108(1): 1-28. https://doi.org/10.1016/j.jfineco.2013.01.003 
Reinganum, M.R. (1983): The Anomalous Stock Market Behavior of Small Firms in January. Journal of Financial Economics, 12(1): 89-104. https://doi.org/10.1016/0304405X(83)90029-6

Ritter, J.R. (1988): The Buying and Selling Behavior of Individual Investors at the Turn of the Year. The Journal of Finance, 43(3): 701-717. https://doi.org/10.1111/j.1540-6261.1988. tb04601.x

Rosenberg, B. (1974): Extra-Market Components of Covariance in Security Returns. The Journal of Financial and Quantitative Analysis, 9(2): 263-274. https://doi. org/10.2307/2330104

Rosenberg, B. - Guy, J. (1976): Prediction of Beta from Investment Fundamentals: Part One, Prediction Criteria. Financial Analysts Journal, 32(3): 60-72. https://doi.org/10.2469/faj. v32.n3.60

Rosenberg, B. - McKibben, W. (1973): The Prediction of Systematic and Specific Risk in Common Stocks. The Journal of Financial and Quantitative Analysis, 8(2): 317-333. https:// doi.org/10.2307/2330027

Rosenberg, B. - Reid, K. - Lanstein, R. (1985): Persuasive Evidence of Market Inefficiency. The Journal of Portfolio Management, 11(3): 9-16. https://doi.org/10.3905/jpm.1985.409007

Ross, S.A. (1976): The Arbitrage Theory of Capital Asset Pricing. Journal of Economic Theory, 13(3): 341-360. https://doi.org/10.1016/0022-0531(76)90046-6

Ruud, P. (2000): An Introduction to Classical Econometric Theory. Oxford University Press, New York.

Sharpe, W.F. (1964): Capital Asset Prices: A Theory of Market Equilibrium under Conditions of Risk. The Journal of Finance, 19(3): 425-442. https://doi.org/10.2307/2977928

Sharpe, W.F. (1966): Mutual Fund Performance. The Journal of Business, 39(1/Part 2): 119138. https://doi.org/10.1086/294846

Wooldridge, J.M. (2013). Introductory Econometrics - A Modern Approach. South-Western, Mason.

Zaremba, A. - Konieczka, P. (2017): Size, Value, and Momentum in Polish Equity Returns: Local or International Factors? International Journal of Management and Economics, 53(3): 26-47. https://doi.org/10.1515/ijme-2017-0017 


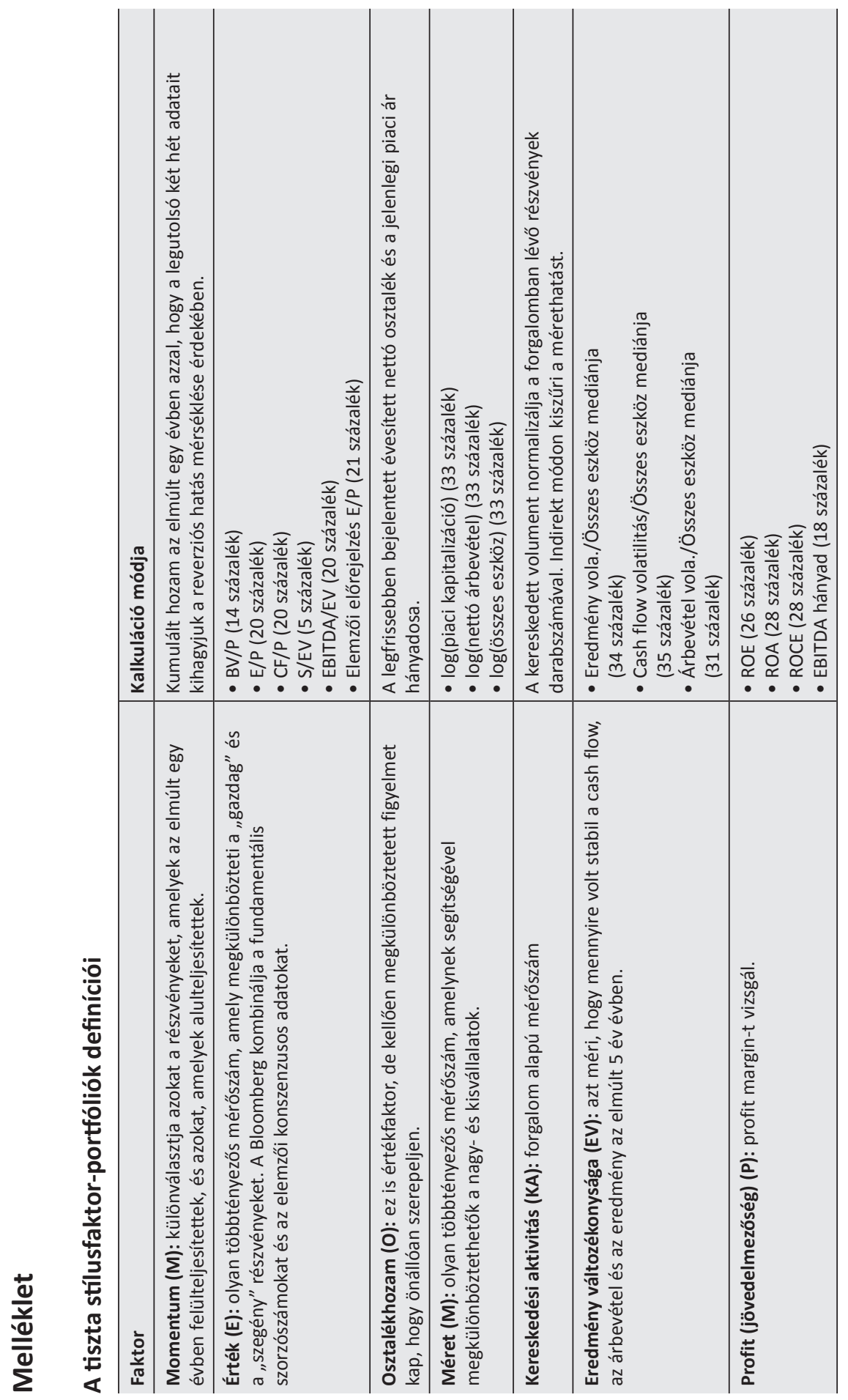




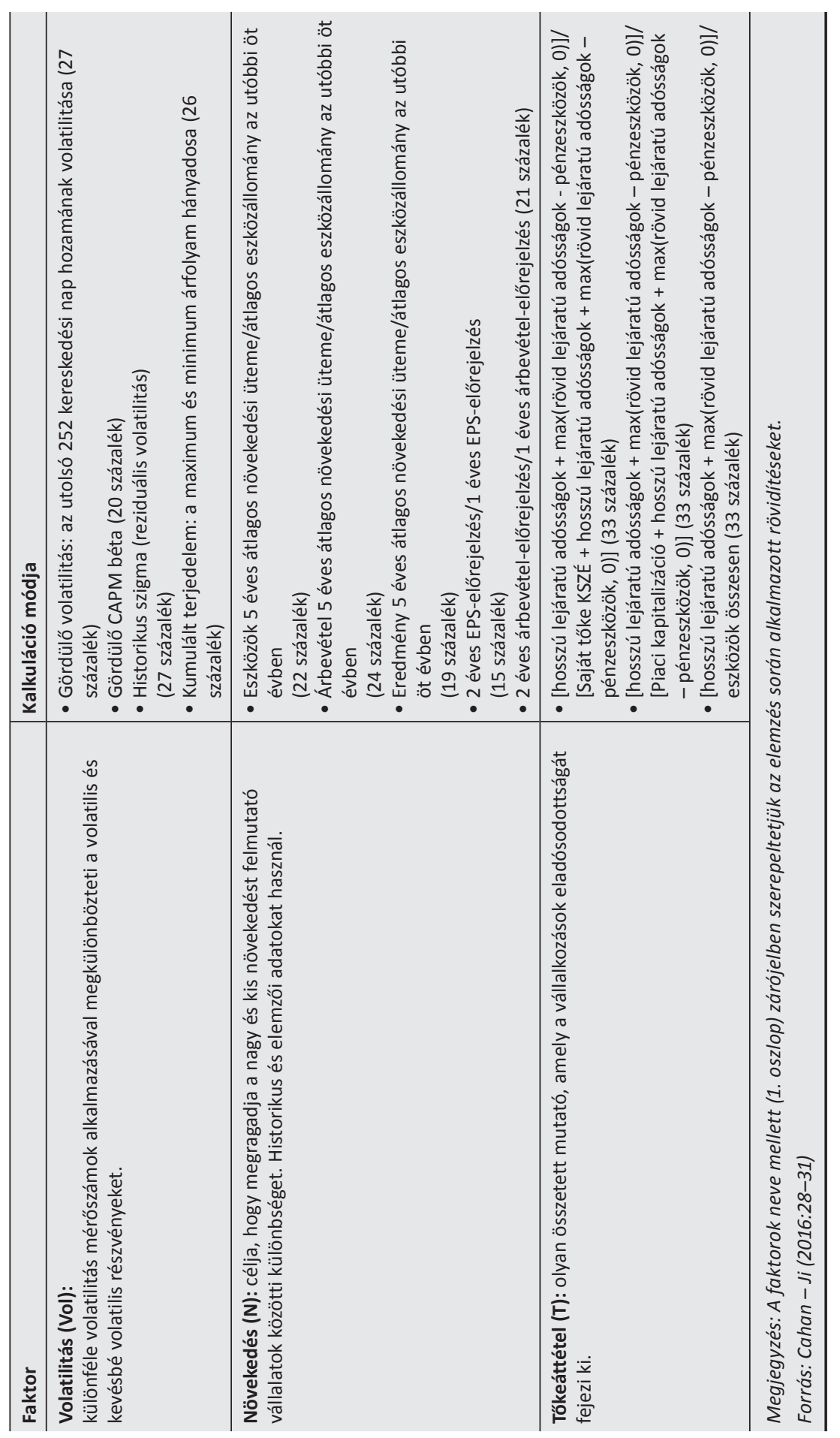

